\title{
THE ELUSIVE MIDDLE GROUND: A PROPOSED CONSTITUTIONAL SPEECH RESTRICTION FOR JUDICIAL SELECTION
}

\author{
NEIL K SETHI $\dagger$
}

INTRODUCTION

I. THE CANDIDATES' AND THE PUBLIC'S INTERESTS IN UNRESTRICTED CAMPAIGN SPEECH.

II. THE STATE'S INTEREST IN PRESERVING THE INTEGRITY OF ITS JUDICIARY OUTWEIGHS A SPEECH RESTRICTION'S ADVERSE CONSEQUENCES FOR CANDIDATES AND THE PUBLIC....... 719

A. The Harms That Judicial-Selection Speech Restrictions Seek to

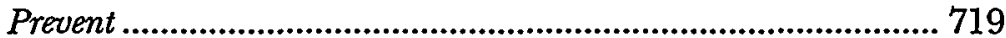

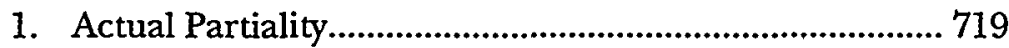

2. The Appearance of Partiality .......................................... 722

3. The Judiciary Must Be Free to Act as a Check on Tyranny by the Majority........................................... 724

4. Allowing Unfettered Speech by Candidates Misleads the Public ............................................................................ 727

B. Responses to Criticisms of Speech Restrictions ............................... 728

1. The Voters Have a Right to the Information................. 728

2. The Voters Need the Information................................ 729

3. Speech Restrictions Are Unnecessary ............................ 733

a. Recusal......................................................................... 733

b. The Public Can Figure It Out ........................................ 735

III. PREVIOUSLY PROPOSED SPEECH RESTRICTIONS .............................. 736

A. The American Bar Association's Speech Restrictions..................... 736

1. The 1924 Canons of Judicial Ethics.............................. 736

2. The 1972 Code of Judicial Conduct............................... 737

† B.A. 1994, Duke University; J.D. Candidate 1997, University of Pennsylvania. First and foremost, I would like to thank my parents, Inder and Lida, my brother, David, and Elizabeth Fenton for their love, support and willingness to pretend to be unflaggingly interested in this Comment. I would also like to thank Professor A. Leo Levin, The Honorable Stewart Dalzell, Chris Abbinante and Peter Ryan for their varied contributions and insightful comments, with special thanks to Peter, who should win whatever award is available for patient executive editors. Lastly, I thank the members of that well-oiled machine known as the University of Pennsylvania Law Review editing staff for their dogged persistence in finding problems in this piece. 
3. The 1990 Model Code of Judicial Conduct ................... 737

4. The Constitutionality of the ABA Restrictions............... 738

a. Decisions Upholding Canon $7 B(1)(c)$........................... 738

b. Decisions Striking Down Canon $7 B(1)(c)$...................... 740

c. Decisions Upholding the Constitutionality of

Canon 5A(3)(d)........................................................... 745

5. Analysis of the Case Law.................................................. 747

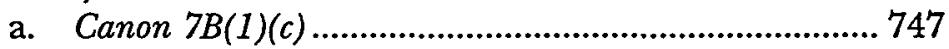

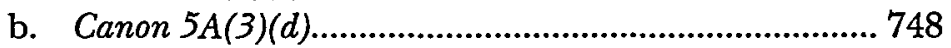

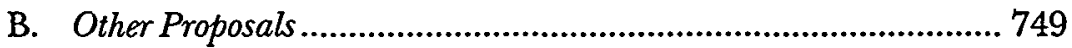

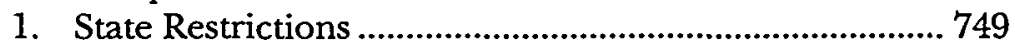

2. Proposals by Commentators ....................................... 751

IV. A CONSTITUTIONAL ALTERNATTVE TO THE ABA'S SPEECH

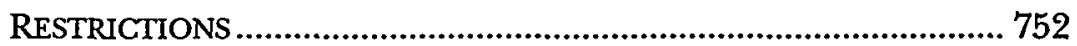

V. APPLICATION TO JUDICIAL APPOINTMENTS................................. 754

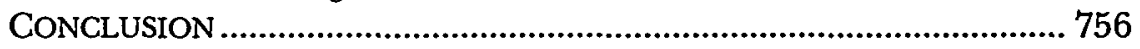

"We must not regard political consequences, however formidable they may be; if rebellion was the certain consequence, we are bound to say 'Let justice be done, though the sky falls."'

\section{INTRODUCTION}

In 1832, swept up in the populist movement known as "Jacksonian Democracy," Mississippi became the first state to elect all of its judges. ${ }^{3}$ In turn, many other states, including every state that joined the Union over the next century, began using elections to select at least some portion of their judiciary. ${ }^{4}$ This preference for elected

${ }^{1}$ 1st Earl of Mansfield, William Murray, at the trial of John Wilkes (1768), in EDMUND HEWARD, LORD MANSFIELD 116 (1979).

2 Named for Andrew Jackson's term as President of the United States. See MARVIN COMISKY \& PHILIP C. PATTERSON, THE JUDICIARY-SELECTION, COMPENSATION, ETHICS, AND DISCIPLINE $\$ 2.1$ (1987) ("Commencing in the first half of the nineteenth century ... the egalitarian philosophy engendered by the Jacksonian revolution resulted in many states opting in favor of popular election of judges, coupled with short terms of office." (footnote omitted)); PATRICK M. MCFADDEN, ELECTING JUSTICE: THE LAW AND ETHICS OF JUDICIAL ELECTION CAMPAIGNS 6-7 (1990) (describing the populist movement which first led states to elect their judiciaries); DANIEL JOHN MEADOR, AMERICAN COURTS 58-59 (1991) (stating that popular election of judges, "unknown in England and in the first decades of the United States, was introduced during the presidency of Andrew Jackson as an aspect of 'Jacksonian democracy").

${ }^{3}$ See MCFADDEN, supra note 2 , at 7.

4 See id. 
judges can be traced both to the general egalitarian mood prevalent at the time $e^{5}$ and to a widespread attempt to increase popular control over government by augmenting its accountability to the people. While a discussion regarding the success of this endeavor is best left for another Comment, ${ }^{7}$ its legacy remains. Many states currently elect some, if not all, of their judges.

See COMISKY \& PATTERSON, supra note 2, § 2.1.

6 See Lawrence Baum, American Courts: Process \& Policy 98 (1990) (noting the United States's "emphasis on accountability in the selection process"); ROBERT A. CARP \& RONALD STIDHAM, JUdICIAL PROCESS IN AMERICA 243 (2d ed. 1993) (theorizing that Americans thought that "[i]f only the average person in his simple innate wisdom could choose the judges, this would put an end to corruption and control of the government by the special (moneyed) interests"); Matthew J. O'Hara, Note, Restriction of Judicial Election Candidates' Free Speech Rights After Buckley: A Compelling Constitutional Limitation?, 70 CHI.-KENT L. REV. 197, 205 (1994) ("The belief that judges were too often wealthy and privileged, and thus insufficiently sympathetic to ordinary people, motivated the early movement toward the popular election of judges." (footnote omitted)).

${ }^{7}$ While an analysis of the appropriateness of elections as opposed to other types of selection systems is beyond the scope of this Comment, it should be noted that many commentators, from Alexander Hamilton to the $\mathrm{ABA}$, have argued strongly against the use of regular judicial elections. See, e.g., THE FEDERALIST No. 78, at 471 (Alexander Hamilton) (Clinton Rossiter ed., 1961) ("Periodical appointments, however regulated, or by whomsoever made, would, in some way or other, be fatal to [the judiciary's] necessary independence."); Stephen B. Bright, Political Attacks on the Judiciary, $80 \mathrm{JU}$. DICATURE 165, 173 (1997) (calling for an end to judicial elections); Steven P. Croley, The Majoritarian Difficulty: Elective Judiciaries and the Rule of Law, 62 U. CHI. L. REV. 689, 713 (1995) (characterizing elections as "the majoritarian difficulty").

${ }^{8}$ There exist today three basic systems for selecting state judges in the United States. These include: pure appointment systems where judges are selected by a state's executive or legislative bodies or by a special commission working singly or jointly; pure election systems where judges are selected in partisan or nonpartisan elections and must periodically be reelected; and "merit selection" systems where judges are appointed, normally by the executive from a list prepared by a special commission, and then must periodically face retention elections where the electorate is asked simply whether or not the judge should be retained. See MCFADDEN, supra note 2, at 5. Although much of this Comment focuses on judicial elections, as discussed throughout and more specifically in Part V, the arguments in favor of speech restrictions apply equally to any type of selection system.

As of 1993, 12 states employed some form of partisan elections to fill at least some judicial vacancies (Alabama, Arkansas, Illinois, Indiana, Mississippi, Missouri, New York, North Carolina, Pennsylvania, Tennessee, Texas and West Virginia), while 17 others utilized nonpartisan elections (Arizona, Florida, Georgia, Idaho, Kentucky, Louisiana, Michigan, Minnesota, Montana, Nevada, North Dakota, Ohio, Oklahoma, Oregon, South Dakota, Washington and Wisconsin). See CARP \& STIDHAM, supra note 6 , at $241-42$ (tables).

As evidenced in 1987 by the overwhelmingly unsuccessful attempt in Ohio to move from elections to a merit selection system, it is unlikely that those states that elect some portion of their judiciary will discontinue doing so anytime in the near future. See John D. Felice \& John C. Kilwein, Strike One, Strike Two ... : The History of and 
Unlike elections for executive or legislative positions, however, candidates for judicial office find themselves in the unique position of being required not to take their constituency's views into account when performing their elected duties.' Instead, judges are bound to administer the law objectively. They must serve as impartial arbiters beholden only to their duty to dispense justice. ${ }^{10}$ This responsibility places elected judges in a particularly delicate position. These judges must curry support in order to be elected; once elected, however, they are required to remain unbiased. While many judges may succeed in carrying out this perverse mandate, in the words of one elected member of the judiciary in the context of an election season, "ignoring the [electoral] consequences of a judicial decision 'would be like ignoring a crocodile in your bathtub." "11

The pressures attendant to judicial decisionmaking are only exacerbated by campaign speech. An illustrative example is a 1981 judicial election where a candidate for judicial office in Kentucky suggested that members of the United Mine Workers Union might receive favorable treatment in his courtroom. ${ }^{12}$ Given that this type of behavior attends even regulated judicial elections, to argue that "there is no evidence that free and open campaign debate diminishes judicial impartiality or the appearance of impartiality,"13 is to ignore reality and the very real potential for abuse that unregulated elections would create. Furthermore, as this Comment will explain, speech re-

Prospect for Judicial Reform in Ohio, 75 JUDICATURE 193 (1992) (examining the voter rejection of a merit selection plan for judges in Ohio).

The District of Columbia and 8 states have no elections whatsoever, with appointment and subsequent confirmation by the governor, legislature and/or a special commission (Connecticut, Delaware, District of Columbia, Hawaii, Maine, New Jersey, South Carolina, Vermont and Virginia). See CARP \& STIDHAM, supra note 6, at 241-42 (tables). With the exception of Massachusetts and Rhode Island (whose judges have tenure until age 70 and for life, respectively), all other states utilize some form of merit selection for their judges. See id. (tables). Many states use a combination of methods depending on the court involved (Arizona, California, Florida, Indiana, Kansas, Michigan, Missouri, New York, Ohio, Oklahoma, South Dakota and Tennessee). See id. (tables).

${ }^{9}$ See Sara mathias, Electing Justice: A Handbook of Judicial Election REFORMS 6 (1990) (noting that popularly elected judges have no constituency, but rather "are charged with applying the law impartially to all those who come before them").

${ }^{10}$ See id.

"Daniel Burke, Code of Judicial Conduct Canon $7 B(1)(c)$ : Toward the Proper Regulation of Speech in Judicial Campaigns, 7 GEO. J. LEGAL ETHICS 181, 182 (1993) (quoting former California Supreme Court Justice Otto Haus) (footnote omitted).

${ }_{12}$ See MCFADDEN, supra note 2, at 90.

is Lloyd B. Snyder, The Constitutionality and Consequences of Restrictions on Campaign Speech by Candidates for Judicial Office, 35 UCLA L. REV. 207, 210 (1987). 
strictions are necessary to protect against more than just explicit promises. Implied promises, such as one candidate's statement that he was a "pro-life candidate," ${ }^{14}$ also severely damage judicial impartiality.

Recognizing the serious need for restrictions on the conduct of judges and judicial candidates in this and many other areas, the American Bar Association ("ABA") in 1924 formulated the Canons of Judicial Ethics ("1924 Canons"), to serve as a model judicial conduct statute. The ABA designed the Canons "as a proper guide and reminder for judges, and as indicating what the people have a right to expect from them." ${ }^{15}$ In 1972, the ABA replaced the 1924 Canons with the Model Code of Judicial Ethics ("1972 Code"). Finally, the 1972 Code was succeeded by the ABA's most recent offering, the 1990 Model Code of Judicial Conduct ("1990 Code"). Most states have closely patterned both their general judicial conduct codes as well as any specific campaign speech restrictions on at least one of these three model provisions. ${ }^{16}$ Each of the ABA codes contains some limitation on the speech of judicial candidates, and all, particularly the 1972 Canons, have been the subject of much criticism. This criticism centers around what is deemed an unwarranted intrusion on the First Amendment rights of judicial candidates. In addition, many feel that limiting judicial candidate speech shields the public from vital information needed to make an informed voting decision and only serves to exacerbate the widespread lack of interest in judicial elections. But even assuming the validity of such arguments, there is nevertheless a need for some type of speech restriction in the context of judicial selection. This Comment attempts to formulate a limitation that best addresses the concerns of speech restriction critics while still providing an effective, workable rule.

In Part I, this Comment will explore the arguments supporting

${ }^{14}$ Deters v. Judicial Retirement \& Removal Comm'n, 873 S.W.2d 200, 203 (Ky. 1994). Deters is discussed, infra, in Part III.A.4.c. For further examples of implied promises, see MCFADDEN, supra note 2, at 90.

${ }^{15}$ CANONS OF JUdiCIAL ETHICS pmbl. (1924).

${ }^{16}$ Currently, 27 states have speech restrictions based upon Canon 7 of the 1972 Code (Alabama, Arkansas, Colorado, Connecticut, Delaware, Florida, Georgia, Illinois, Kentucky, Louisiana, Maryland, Massachusetts, Michigan, Minnesota, Missouri, New Hampshire, New Jersey, New York, North Carolina, Oklahoma, Pennsylvania, South Carolina, Tennessee, Utah, Vermont, Virginia and Washington), while seven states have regulations based upon Canon 5 of the 1990 Code (Arizona, California, Indiana, Maine, Nevada, Texas and West Virginia). See J. David Rowe, Note, A Constitutional Alternative to the ABA's Gag Rules on Judicial Campaign Speech, 73 TEX. L. REV. 597, nn.29 \& 35 (1995). 
the free speech of judicial candidates. Part II examines the interests that speech restrictions protect and demonstrates why considerations for an impartial judiciary trump, at least to some extent, the free speech issues discussed in Part I. Part III will survey the attempts by the $\mathrm{ABA}$, some states and various commentators to create a meaningful speech restriction, and the problems that accompany each of these proposals. This Part will also demonstrate that the subsequent interpretation of any proposed rule is as important as the rule's text. Part IV proposes a new rule and explains how it must be construed in order to achieve the goal of an impartial judiciary. Finally, Part V will discuss the applicability of the proposed regulation beyond judicial elections to all types of judicial selection.

\section{THE CANDIDATES' AND THE PUBLIC'S INTERESTSS IN UNRESTRICTED CAMPAIGN SPEECH}

The difficulty in devising a restriction on the speech of judicial candidates is that any rule attempting to reconcile the competing principles of freedom of speech and impartial legal justice invariably will involve serious tradeoffs. In contrast, developing a rule at either extreme is easy. One could either allow candidates to say whatever they want, or alternatively, prohibit them from saying anything at all that might reveal their opinions regarding an issue. Such solutions, though easily enforceable, completely eradicate the significant concerns of the other side. As Judge Posner has recognized, "[w] hatever their respective pedigrees, only a fanatic would suppose that one of the principles should give way completely to the other." examines the interests advanced by unrestricted campaign speech. Part II, in turn, will discuss the interests on the other side-those protected by speech restrictions-and why those concerns must take precedence over the candidates' and public's interest in having no restriction at all.

The first and possibly most significant interest of both candidates and the public in unrestricted campaign speech is the flow of information. ${ }^{18}$ Candidates have a strong need to convey information about themselves and their campaign platform. ${ }^{19}$ Likewise, voters, as well as

${ }^{17}$ Buckley v. Illinois Judicial Inquiry Bd., 997 F.2d 224, 227 (7th Cir. 1993).

${ }^{18}$ It should be noted at this point that it is not the flow of information itself which speech restrictions seek to prohibit, but rather explicit or implicit promises which accompany a candidate's pronouncement of her views on issues which may come before her.

${ }^{19}$ See Harky P. Stumpf \& John H. Culver, The Politics of State Courts $46-47$ 
other types of selectors, require such information if they are to make an informed choice. ${ }^{20}$ A lack of information regarding the candidates harms both of these parties, as the selector cannot differentiate among those running for office.

The consequences of a situation where voters have insufficient information have been well chronicled by opponents of judicial speech restrictions. $^{21}$ One ramification is that voters often become apathetic. $^{22}$ This results not only from the public's inability to discriminate between the candidates, but also from a general lack of media interest in judicial elections. ${ }^{23}$ Many commentators argue that when judicial candidates are not permitted to discuss how they will decide controversial issues (or their general beliefs about such issues), both the electorate and the media lose interest. As a result, not only do voters remain relatively uninformed about judicial candidates, but many lack sufficient interest in the outcome to cast a ballot, even when they are already standing in the voting booth. ${ }^{24}$

(1992) (describing some of the apparently random factors that, in the absence of information, could determine an election, including: whether the name of the candidate sounds familiar to the voters; whether terms such as "incumbent" are used before the candidate's name on the ballot; or whether the name of the candidate suggests a certain ethnic origin). For a discussion of the type of information a candidate should legitimately be permitted to disseminate, see infra notes 87-94 and accompanying text.

${ }_{20}$ See STUMPF \& CULVER, supra note 19, at 46-47; Snyder, supra note 13, at 216 ("Freedom to express views is necessary if the public is to make fair judgments among the candidates who seek office.").

${ }_{21}$ Although, at least to some extent, these concerns may be applied to all types of selectors, these commentators have focused almost exclusively on their impact on elections.

${ }^{22}$ See David W. Case, In Search of an Independent Judiciary: Alternatives to Judicial Elections in Mississippi, 13 MISs. C. L. REV. 1, 11, 21 (1992) (noting low voter turnout in both Mississippi's partisan and nonpartisan judicial elections); Bridget E. Montgomery \&: Christopher C. Conner, Partisan Elections: The Albatross of Pennsylvania's Appellate Judiciary, 98 DICK. L. REV. 1, $20-22$ (1993) (voter apathy); Peter D. Webster, Selection and Retention of Judges: Is There One "Best" Method?, 23 FLA. ST. U. L. REV. 1, 26 (1995) (noting widespread voter apathy in judicial elections, particularly in nonpartisan races).

${ }^{23}$ See MATHIAS, supra note 9 , at 11 (discussing the media's relationship to the judicial election process).

${ }_{24}$ One study found that the "average rolloff (i.e., the percentage of the voters who cast ballots for the lead partisan office on the ballot but fail to vote in the judicial retention election) for ... 1,864 retention elections [wa]s 36.2[\%]." William $\mathrm{K}$. Hall \& Larry T. Aspin, What Twenty Years of Judicial Retention Elections Have Told Us, 70 JUDICATURE 340, 346-47 (1987). While the rolloff for retention elections-which are normally uncontested-probably exceeds that of normal judicial elections, such results still clearly indicate a lack of voter interest. Other poll statistics similarly reflect voter apathy. For example, only $14.2 \%$ of a Texas city's voters in a state general election were able to identify a single judicial candidate after they had voted. See MATHIAS, supra note 9 , at 17 (citing statistics that demonstrate electorate ignorance). 
A second consequence of insufficient voter information is that when voters cannot distinguish between candidates on legitimate grounds, they are forced to resort to the information they do have. ${ }^{25}$ Such information always includes the candidate's name and often includes sex, race, age and political affiliation. While all but the last of these criteria should be illegitimate identifiers, opponents of speech restrictions argue that voters must rely on them because the public has nothing else. ${ }^{26}$

In addition to the practical difficulties that accompany an election where candidates may relate only limited information to the public, speech restrictions also implicate the First Amendment. ${ }^{27}$ The First and Fourteenth Amendments to the United States Constitution protect a citizen's right to free speech. ${ }^{28}$ In Buckley $v$. Valeo, ${ }^{29}$ the Supreme Court further found that "it is of particular importance that candidates have the unfettered opportunity to make their views known so that the electorate may intelligently evaluate the candidates' personal qualities and their positions on vital public issues." ${ }^{30}$ In Brown v. Hartlage, the Court expanded on this theme, holding that the First Amendment prohibited a state from attempting to prevent a candidate for county commissioner from making promises that would benefit a particular class of voters. ${ }^{31}$ The Court in Brown, however, recognized that a candidate's right to speak freely is not without limits. The Court stated that a limitation on a candidate's speech would

${ }^{25}$ See STUMPF \& CULVER, supra note 19 , at $46-47$.

${ }^{26}$ See Montgomery \& Conner, supra note 22 , at 10 (finding that voters often utilize criteria "extraneous to judicial qualifications"); Webster, supra note 22 , at 26 (stating that voters in judicial elections often cast their ballots based upon "irrelevant factors, such as ballot position and name"). But see Harry L. Witte, Judicial Selection in the Peaple's Democratic Republic of Pennsylvania: Here the People Rule?, 68 TEMPLE L. REV. 1079, 1143 (1995) ("Even if the voter knows nothing about the candidate other than the party label, that information is still quite useful.").

${ }^{27}$ See Monitor Patriot Co. v. Roy, 401 U.S. 265, 272 (1971) (finding that the First Amendment's "fullest and most urgent application [is] precisely to the conduct of campaigns for political office").

${ }^{28}$ The First Amendment states that "Congress shall make no law ... abridging the freedom of speech." U.S. CONST. amend. I. The Fourteenth Amendment extends the protections of the First Amendment to state citizens. See, e.g., Gentile v. State Bar, 501 U.S. 1030, 1033 (1991) (finding the application of a Nevada rule restricting the speech of attorneys to be violative of the First Amendment).

${ }^{29} 424$ U.S. 1 (1976) (per curiam) (striking down portions of the Federal Election Campaign Act of 1971).

Id. at 52-53.

31 456 U.S. $45,58-59$ (1982) (“[A] candidate's promise to confer some ultimate benefit on the voter, qua taxpayer, citizen, or member of the general public does not lie beyond the pale of First Amendment protection."). 
be constitutional if the state could demonstrate that it had "not only a legitimate state interest, but a compelling one, and that the restriction operate[s] without unnecessarily circumscribing protected expression." $"$ 2

While the Supreme Court has thus set the standard for encroaching upon the First Amendment rights of election candidates very high, courts have also recognized that judicial elections involve distinct problems. Judges differ from legislators in many ways, and restrictions that might not be appropriate if applied to the legislative and executive branches may be legitimate if applied to the judiciary. ${ }^{35}$

\section{THE STATE'S INTEREST IN PRESERVING THE INTEGRITY OF ITS JUDICIARY OUTWEIGHS A SPEECH RESTRICTION'S ADVERSE CONSEQUENCES FOR CANDIDATES AND THE PUBLIC}

While the arguments in support of a candidate's unrestricted right to speak are persuasive, they must nevertheless be subordinated, at least with respect to those statements that materially implicate the impartiality of the judiciary. The consequences that follow from certain statements made by judicial candidates are far more severe than those that accompany limited speech restrictions. Judicial partiality violates the most basic principles upon which this country's judicial system was founded and through which it has been legitimized. Additionally, most of the arguments opposing speech restrictions do not withstand scrutiny.

\section{A. The Harms That Judicial-Selection Speech Restrictions Seek to Prevent}

\section{Actual Partiality}

When a judicial candidate makes a statement regarding her beliefs on an important public issue (whether it be her views, for example, on abortion, the death penalty or crime in general) and is subsequently elected, there is an impermissible risk that the judge will no longer view that issue impartially. ${ }^{34}$ There are a number of levels on

${ }^{92}$ Id. at 53-54.

${ }^{33}$ See, e.g., Buckley v. Illinois Judicial Inquiry Bd., 997 F.2d 224, 228 (7th Cir. 1993) ("Judges remain different from legislators and executive officials, even when all are elected, in ways that bear on the strength of the state's interest in restricting their freedom of speech.").

${ }^{34}$ It must be stressed that this Comment does not take as a premise that judges are always impartial or that speech restrictions will eliminate all pressures to rule in conformity with the wishes of the majority. Such difficulties are inherent in a system of 
which actual partiality may occur. For example, assume that a candidate states that she is pro-life and thereafter is elected to the bench. First, if the judge is assigned a case dealing with an abortion issue, the judge will naturally feel pressure to act in conformity with her prior commitment in order to avoid appearing untrustworthy to the electorate. ${ }^{35}$ A sensational case and/or the possibility of an election looming on the horizon would only increase such pressure. ${ }^{36}$ In addition, the judge may feel a moral commitment to act in conformity with her previous statements to the public.

Second, even if the judge were determined not to be influenced by her campaign assertions, it is possible that, in making certain she is not biased against one party, she will become so against the other. In this case, the judge holds the side she is expected to favor to a higher standard than she normally would have in order to compensate for her perceived bias. This dilemma may arise even if the judge merely faces a litigant who is strongly linked with one side of the abortion issue. Ironically, in order to prevent any appearance of prejudice, the judge becomes biased.

In addition to these conscious pressures that may influence a judge to act partially, psychological data suggest a number of further dangers. First, in the negotiation context, studies have found that simply exposing an individual to an audience causes that person to

electing judges. Professor Croley refers to this inclination to rule in a manner consistent with the wishes of the majority as the "[b]iased administration of day-to-day justice." Croley, supra note 7, at 728. Similarly, although other parties might easily do what the candidate is prohibited from doing by endorsing or advertising for her, the analysis does not change. It is not the dissemination of information itself which must be proscribed, but rather the implied promises by the candidate. If elections are to be utilized, the electorate should have as much legitimate information as possible. The fact that a given judge is a conservative, a textualist or an environmentalist should be communicated to the public and is important for any voter's informed decision. This Comment simply takes issue with one way in which this goal might be accomplished. Having the judicial candidate herself espouse her views creates the dangers discussed herein and so must be prohibited. It is that activity which results in implied promises of conduct, not the spread of the information itself. Even if a judge would have been biased without the above public statement, the forces discussed in this Section would act to make her even more biased.

${ }^{33}$ The rise of the single-issue voting bloc, where voters focus on only a narrow subset of a judge's record, has exacerbated this problem. See STUMPF \& CULver, supra note 19, at 45-46 ("The rise of single-issue voting blocs has resulted in some jurists being forced to defend themselves for having voted a particular way on controversial issues.").

${ }^{36}$ In the words of former California Supreme Court Justice Otto Haus, "' $[t]$ here's no way a judge is going to be able to ignore the political consequences of certain decisions, especially if he or she has to make them near election time." Paul Reidinger, The Politics of Judging, A.B.A. J., Apr. 1, 1987, at 52, 58 (quoting Justice Haus). 
act in a manner of which the audience will approve. ${ }^{37}$ Exposure to an audience whose opinion the individual values accentuates this result. ${ }^{38}$ The application of these findings to judicial decisionmaking is obvious. Furthermore, if the negotiator is held "accountable" for his performance (e.g., when the audience is a constituency), the audience will "generally insist that he be tough, firm, demanding, and unyielding" and "[f]ailure to perform in this manner (in the eyes of the audience) may lead to public criticism of the negotiator, with the expectation that this criticism will 'embarrass' him into performing in ways that guarantee a larger payoff for the constituency." the individual feels "strong pressures ... to be a loyal, committed, and dedicated advocate of the constituency's preferred outcomes and priorities." ${ }^{40}$ Although these results suggest a problem with judicial elections in general, a candidate's statements that are interpreted as promises of future conduct serve to heighten these pressures by eliminating any doubt as to the expectations of the constituency. Such pressures are clearly incompatible with neutral, detached decisionmaking.

A final potential danger in allowing judicial candidates to state their views on issues that might come before them is that, if elected, it is likely that the judge will not view new information on that issue impartially. The well-known theory of cognitive dissonance states that if two or more of a person's attitudes or beliefs are in conflict, the person will try to reduce or eliminate that conflict either by changing one of the attitudes or by creating an explanation for the apparent inconsistency. ${ }^{4 l}$ The studies suggest that individuals either try to find "reasons" to support their beliefs or they change them. Thus, for example, heavy smokers either discount information regarding the dangers of smoking or they quit. ${ }^{42}$ Judicial candidates who make statements regarding issues that subsequently come before them similarly may discount information-such as the argument of a criminal de-

${ }^{37}$ See ROY J. LEWICKI \& JOSEPH A. LITTERER, NEGOTIATION 218 (1985) ("The mere presence of an audience motivates a negotiator to seek a favorable (positive) evaluation from the audience....").

${ }^{38}$ See id. at 219 ("[T] he presence of a 'salient' audience ... affects a negotiator even more dramatically.").

${ }^{39} I d$. at 221.

${ }^{40} \mathrm{Id}$.

41 See Nicky Hayes, Foundations of PSYCHOLOGY 623 (1994); JEROME KAGAN \& JULIUS SEGAL, PSYCHOLOGY: AN INTRODUCTORY TEXT 582 (6th ed. 1988); B. VON HALLER GILMER, PSYCHOLOGY 406-07 (2d ed. 1973).

42 See VON HALLER GILMER, supra note 41 , at 406 . 
fendant or abortion-rights activist-in order to maintain consonance with their pre-election statements. Furthermore, studies have demonstrated that behavior often influences a person's beliefs. ${ }^{43}$ For example, simply taking a position has been found to be enough to change attitudes. ${ }^{44}$ Activities such as writing a paper ${ }^{45}$ or just telling others that a tedious activity had been interesting ${ }^{46}$ were found to result in profound changes in attitude. Thus it seems that "the weighing of alternatives is more realistic before we reach a decision." ${ }^{47}$ These studies clearly apply to the arena of judicial campaign speech where candidates are constantly taking public positions on issues and will consequently be less likely to be impartial when confronted with that issue as a judge, no matter what their prior bias, if any, had been.

Such partiality would threaten the very foundations of the justice system in the United States. The view that judges should be impartial is an ancient one. The Book of Deuteronomy states that

[y] ou shall appoint judges and officials throughout your tribes, in all your towns that the Lord your God is giving you, and they shall render just decisions for the people. You must not distort justice; you must not show partiality; and you must not accept bribes, for a bribe blinds the eyes of the wise and subverts the cause of those who are in the right. ${ }^{48}$

This conception of "justice" remains the same today, often defined in terms of "fairness," in one's dealings and actions." ${ }^{, 50}$ The actual partiality of judges is clearly incompatible with such a standard.

\section{The Appearance of Partiality}

Some speech restriction opponents argue that there is no evidence that statements made by judicial candidates influence their decisions. ${ }^{51}$ Even assuming that this assertion is correct, speech restric-

43 See KaGaN \& SEgaL, supra note 41, at 583.

44 See HAYES, supra note 41, at 624-25; VON HALLER GILMER, supra note 41, at 407.

45 See HAYES, supra note 41, at 624-25; KAGAN \& SEGAL, supra note 41, at 583.

40 See HAYES, supra note 41 , at 624; VON HALLER GILMER, supra note 41, at 407.

47 VON HALLER GILMER, supra note 41 , at 407.

48 Deuteronomy 16:18-19 (New Revised Standard).

${ }^{49}$ THE AMERICAN HERITAGE DICTIONARY OF THE ENGLISH LANGUAGE 979 (3d ed. 1992) (defining "justice").

50 Id. (defining "just").

${ }^{51}$ See Snyder, supra note 13, at 232-35. It must be noted that a lack of evidence does not necessarily suggest that there is no correlation, as this dearth of proof exists on both sides of the issue. Similarly, the argument that speech restrictions are underinclusive because they only address the comments of judicial candidates as opposed to 
tions are still necessary to protect against what is perhaps a greater evil: the appearance of partiality. If the hypothetical judge discussed above manages to follow her duty to view each case neutrally and is totally uninfluenced by her statement that she "is a pro-life candidate," actual partiality will have been avoided. To the public, however, even with respect to cases that simply involve abortion-rights or anti-abortion litigants, ${ }^{52}$ it may still appear that the judge's bias tainted the decisions. More importantly, in such a situation the judge will probably be faulted no matter what the outcome. If the judge rules in a manner consistent with her previous statements, it will appear that she has not acted impartially. (This also impugns the credibility of the judicial system.) If the judge rules against her prior commitments, then she becomes vulnerable to attacks on her trustworthiness.

The appearance of partiality is perhaps more destructive than actual partiality because it erodes the faith of the people in the system itself. Society must respect and believe in the judiciary or the system forfeits its legitimacy. ${ }^{53}$ Litigants, especially those who do not prevail,

statements made by lawyers and judges before they become candidates is specious at best. See id. at 230 (asserting that the underinclusive nature of campaign speech restrictions undermines any argument that they serve the public interest); see also O'Hara, supra note 6, at 232 (arguing that the fear that elected judges will be constrained by their public statements proves too much because "all judges are constrained by the positions they have adopted in previous decisions on legal and policy issues" (emphasis added)); Kathleen Margaret Sholette, Recent Development, Canon 7 Restrictions on the Political Speech of Judicial Candidates: Judging Those Who Would Be Judges, 37 VILL. L. REV. 139, 159-60 (1992) (arguing that the speech of judicial candidates should be restricted only with respect to issues that would likely come before the court once the candidate was appointed). While it can be argued that some type of implicit mandate results from the election of a candidate with clearly held beliefs, such a case does not present as great a pressure on the candidate as when she herself promises particular activity. The problem of an implied mandate, as opposed to an implied promise, is a creature of the judicial election process itself and can only be avoided through the abolition of judicial elections. In contrast, the speech restriction proposed in this Comment would only do away with implied promises and their concomitant harms.

${ }^{52}$ This danger even extends to cases where the subject matter is not abortion. If, for example, the litigant were a doctor in an abortion clinic and were involved in a non-abortion-related case, the same analysis would apply.

${ }^{53}$ See ALEXANDER M. BICKEL, THE LEAST DANGEROUS BRANCH 29 (1962).

[L] egitimacy comes to a regime that is felt to be good and to have proven itself as such to generations past as well as present. Such a government must be principled as well as responsible ... and unless it is responsible it cannot in fact be stable, and is not in my view morally supportable.

Id. This function of legitimizing plays an especially crucial role with respect to criminal sanctions. See Peter Arenella, Rethinking the Functions of Criminal Procedure: The Warren and Burger Courts' Competing Ideologies, 72 GEO. L.J. 185, 200 (1983) ("Since the state monopolizes the use of physical violence, it must validate its monopoly by providing impersonal criteria for resolving conflicts with its citizens."). 
must believe that judicial decisions are made on the basis of neutral criteria and are grounded on more than the judge's personal feelings. ${ }^{54}$ As the Third Circuit has noted, "[i]f judicial candidates during a campaign prejudice cases that later come before them, the concept of impartial justice becomes a mockery. The ideal of an adjudication reached after a fair hearing ... no longer would apply and the confidence of the public in the rule of law would be undermined. ${ }^{55}$ The public, in such a situation, would view the court system with irreverence and contempt, and might go so far as to take affirmative action to disobey or obstruct it. ${ }^{56}$

\section{The Judiciary Must Be Free to Act as a Check on Tyranny by the Majority}

The United States is often thought of as a country where the majority rules. The political reality, however, is that America is not a "true democracy." While the executive and legislative branches are popularly elected and, at least in theory, exist to effectuate the will of the majority, the judicial branch acts as a check on that will. ${ }^{58}$ Despite

${ }^{54}$ Paul D. Carrington, The New Order in Judicial Rulemaking, 75 JUDICATURE 161, 162 (1991).

The paramount role of courts in our tradition is to earn and keep the trust of the whole public .... Essential to the performance of that role is the practice by the courts of classical civic virtue, of being and seeming to be impartial, disinterested, independent of action, or at least partaking of those traits within the limits of human capacity.

Id.

${ }^{55}$ Stretton v. Disciplinary Bd., 944 F.2d 137, 142 (3d Cir. 1991); see also Mapp v. Ohio, 367 U.S. 643, 659 (1961) ("Nothing can destroy a government more quickly than its failure to observe its own laws, or worse, its disregard of the charter of its own existence."). The idea that courts must at least appear to decide cases on the basis of neutral principles utilizing sound reasoning has been recognized in many contexts, such as the need for written appellate opinions, see Paul D. Carrington, Ceremony and Realism: Demise of Appellate Procedure, 66 A.B.A. J. 860 (1980), and the use of staff attorneys for opinion writing, see Wade H. McCree, Jr., Bureaucratic Justice: An Early Warning, 129 U. PA. L. REV. 777, 789 (1981) (noting a "stark contrast between poorly reasoned and written opinions and our fundamental expectation that judicial decisions will be accompanied by reasoned justifications").

${ }^{36}$ See Olmstead v. United States, 277 U.S. 438, 485 (1928) (Brandeis, J., dissenting) ("Our Government is the potent, the omnipresent teacher. For good or for ill, it teaches the whole people by its example .... If the Government becomes a lawbreaker, it breeds contempt for law; it invites every man to become a law unto himself; it invites anarchy."); CARP \& STIDHAM, supra note 6, at 302.

57 See Rowe, supra note 16, at 618-19.

${ }^{58}$ See MEADOR, supra note 2, at 3 (discussing judicial review as a "major element[] in the American conception of the 'rule of law'"); Croley, supra note 7, at 703-06 
some criticism of judicial review as antidemocratic, ${ }^{59}$ in the American system this separation of powers is "fundamental to liberty and to government under law."

The view that the judiciary should perform such a function dates to the inception of the nation. In The Federalist No. 78, Alexander Hamilton described the judiciary "as the bulwark [] of a limited Constitution against legislative encroachments." Chief Justice John Marshall expanded upon this idea in Marbury v. Madison. ${ }^{62}$ Establishing the framework of judicial review in Marbury, Marshall echoed Hamilton's notion that " $\mathrm{t}]$ he powers of the legislature are defined and limited," ${ }^{\text {,is }}$ and announced that in determining when the legislature had crossed those limits, "[i]t is emphatically the province and duty of the judicial department to say what the law is."

As Hamilton observed, if the judiciary is to act as "an intermediate body between the people and the legislature in order . . . to keep thè

(discussing "[t]he Protection Principle of Constitutionalism" which states that "[m]ajoritarian authority is limited by the constitutional rights individuals hold against the majority" and finding that "[c]onstitutions embody this principle ... by providing certain checks on majoritarian decisions" such as judicial review); Rowe, supra note 16, at $617-19$ (reconciling the concept of judicial review with popular sovereignty).

59 See BICKEL, supra note 53, at 16-23 (characterizing the judicial branch as the "Counter-Majoritarian Difficulty"); PHILIP BOBBITT, CONSTITUTIONAL INTERPRETATION 6 (1991) (describing the judiciary as the "Countermajoritarian Objection").

${ }^{60}$ MEADOR, supra note 2, at 2; see Rowe, supra note 16, at 619 ("CJ]udicial review is actually necessary to our form of government."). While a detailed discussion of whether judicial review is consistent with democracy is beyond the scope of this Comment, see BICKEL, supra note 53 and Croley, supra note 7, for excellent treatments of this topic-the latter also suggesting that elective judiciaries are inconsistent with a constitutional democracy.

61 THE FEDERALIST No. 78, supra note 7, at 469.

625 U.S. (1 Cranch) 137 (1803); see BICKEL, supra note 53, at 16 (stating that Marshall looked to The Federalist No. 78 in coming to his decision in Marbury); GEOFFREY R. STONE ET AL., CONSTITUTIONAL LAW, 33-34 (2d ed. 1991) (noting that " $[t]$ he relevant documents [including The Federalist No. 78] at the time of the framing indicate that judicial review was generally contemplated").

${ }_{63}$ Marbury, 5 U.S. (1 Cranch) at 176.

${ }^{64} I d$. at 177 . While the concept of judicial review of the actions of the other branches of government had its origins over two centuries ago, its necessity has been recognized by modern commentators. Paul Carrington, for example, has noted that "[t]he aspiration and the role [of the courts] was to balance the influences of factional interests manifested in the work of other organs of government." Carrington, supra note 54, at 162. Similarly, former justice of the Tennessee Supreme Court Penny White has noted that, in the absence of judicial review, "[p]oll taxes, literacy tests, loyalty oaths, political gerrymandering, segregated public accommodations, and lynchings would all have survived because the judiciary would have been powerless to question, let alone invalidate, the actions of the legislative or executive branches." Penny J. White, An America Without Judicial Independence, 80 JUDICATURE 174, 175 (1997). 
latter within the limits assigned to their authority," 65 " $[t]$ he complete independence of the courts of justice is ... essential." "Hamilton further believed that this independence should extend beyond mere independence from the other branches of government. The courts had to be free from the will of the people, as well, if the courts were "to guard the Constitution and the rights of individuals from ... those ill humors which the arts of designing men, or the influence of particular conjunctures, sometimes disseminate among the people themselves." ${ }^{67}$

Hamilton clearly articulated the need for the judiciary to serve as a guardian of the rights of minorities who lacked the political force to protect their interests:

But it is not with a view to infractions of the Constitution only that the independence of the judges may be an essential safeguard against the effects of occasional ill humors in the society. These sometimes extend no farther than to the injury of the private rights of particular classes of citizens, by unjust and partial laws. Here also the firmness of the judicial magistracy is of vast importance in mitigating the severity and confining the operation of such laws. ${ }^{68}$

The Supreme Court has explicitly recognized the propriety of such a role for the judiciary. In the famous fourth footnote of United States v. Carolene Products Co.," the Court asserted that "prejudice against discrete and insular minorities may be a special condition, which tends seriously to curtail the operation of those political processes ordinarily to be relied upon to protect minorities, and which may call for a correspondingly more searching judicial inquiry." This footnote began the formation of the strict scrutiny requirement which the Court now utilizes in such cases. ${ }^{71}$ In performing its check-

${ }_{66}^{65}$ THE FEDERALIST No. 78, supra note 7, at 467.

Id. at 466 .

${ }^{67} I d$. at 469; see also BICKEL, supra note 53, at 26 ("Their insulation and the marvelous mystery of time give courts the capacity to appeal to men's better natures, to call forth their aspirations, which may have been forgotten in the moment's hue and cry.").

THE FEDERALIST No. 78, supra note 7, at 470; see also Note, Formalism, Legal Realism, and Constitutionally Protected Privacy Under the Fourth and Fifth Amendments, 90 HARV. L. REV. 945, 987 (1977) (arguing that "to deprive the minority of human dignity and equality under the law [is to] deny the political importance of those singled out by the majority's enactment and enforcement of the ... law," and that it is "the duty of the courts" to protect against such abuses).

304 U.S. 144 (1938).

${ }^{7} I$. at $153 \mathrm{n} .4$.

7 See, e.g., Korematsu v. United States, 323 U.S. 214, 216 (1944) ("[A]ll legal restrictions which curtail the civil rights of a single racial group are immediately suspect 
ing function, the judiciary must be free both from the influence of the other branches of the government and from the will of the people if it is to protect minorities from majority overreaching. As one former judge has noted, "those who want judges to rule based on majority public opinion have never been in the minority."

To demonstrate how this protective function could be subverted by unrestricted judicial election campaigns, imagine a hypothetical judicial candidate who, during the selection process, makes a statement that she would be "tough on criminals." Assuming the candidate is elected, she might be confronted as a judge with an appeal from a defendant who challenges his conviction by arguing that a state statute infringes his rights under that state's constitution. To understand fully the potential ramifications of such a situation, imagine that it is a right not found in, or not as strictly enforced under, the Federal Constitution. The pressures discussed earlier in this Comment would influence the judge to vote consistently with her prior statement. If all of the justices of a state's highest court were selected based on anti-crime campaigns, the result could well be the removal of the check of judicial review with respect to the rights of criminals under the state's constitution. ${ }^{73}$ Such a situation obviously does little to protect the rights of those minorities currently disfavored by the majority. ${ }^{74}$

\section{Allowing Unfettered Speech by Candidates Misleads the Public}

Perhaps the most overlooked harm arising from unfettered judicial campaign speech is that citizens may be misled into believing that

.... [C]ourts must subject them to the most rigid scrutiny.").

${ }^{72}$ White, supra note 64 , at 177 . White continued: "Let us remind the public that a judge who looks to another branch of government to be told how to rule on important legal and social issues is not doing his or her job and is risking the freedom of us all." Id.

73 This analysis obviously is meant to apply to any issue that would sufficiently animate the electorate so as to be the basis of a voting decision. To use an even more striking example, it is almost inconceivable that an elected state supreme court in the South in the 1950s would have come to a decision such as Brown v. Board of Education, 347 U.S. 483 (1954).

${ }^{74}$ Although most of this Section would apply equally to an argument against elected judges, it should be reemphasized that such a position is beyond the scope of this Comment. This Comment argues simply that because the majority can be expected to elect judges who share its views, the partiality concerns discussed previously will predictably weigh more heavily on minorities. Thus, if pro-choice voters constituted the majority, they would elect those judges who stated they were pro-choice, which would generally bias or appear to bias those judges against anti-abortion litigants. 
information which in reality has little relevance to judicial performance is a factor upon which to base their vote. "Sitting judges ... have strongly suggested that [personal] views are not relevant, or at least not nearly so relevant as continuous discussion of them during a judicial campaign would imply." ${ }^{, 5}$ If these judges are correct, then discourse regarding issues that are likely to come before the court might be restricted for this reason alone. ${ }^{76}$

The potential for the public to place undue emphasis on a candidate's implied promises of conduct is exemplified by the election of Stephen Mansfield to the Texas Court of Criminal Appeals. Mansfield campaigned "on promises of greater use of the death penalty, greater use of the harmless-error doctrine, and sanctions for attorneys who file 'frivolous appeals especially in death penalty cases.",77 However,

[b] efore the election it came to light that Mansfield had misrepresented his prior background, experience, and record, that he had been fined for practicing law without a license in Florida, and that-contrary to his assertions that he had experience in criminal cases and had written extensively on criminal and civil justice issues-he had virtually no experience in criminal law. Nevertheless, Mansfield received fifty-four percent of the vote in the general election, defeating the incumbent judge, a conservative former prosecutor who had served twelve years on the court and had been supported by both sides of the criminal bar. ${ }^{78}$

There can be little question that the electorate in this case ignored questions about Mansfield's integrity and qualificationsarguably the two most important factors in selecting a judge-and chose him based solely on his promises. In reality, of course, such promises should play no role in the decision of a particular case, as Mansfield will be bound to administer the law objectively.

\section{B. Responses to Criticisms of Speech Restrictions}

\section{The Voters Have a Right to the Information}

Many critics of speech restrictions contend that the citizenry-the source of governmental power and legitimacy in the United Stateshas a right to know the beliefs of judicial candidates who, if elected,

75 MCFADDEN, supra note 2, at 89.

${ }^{76}$ See id. at 88-89 (arguing for a prohibition of discussion of "disputed legal and political issues," not just discussion of issues likely to come before the court).

77 Bright, supra note 7, at 171 .

${ }^{78}$ Id. 
will be involved in the daily governing of the country. ${ }^{79}$ Given that, at least in some cases, judges will look to their personal views to assist them in making decisions, ${ }^{80}$ there may appear to be some merit to the view that the public is entitled to know what judicial candidates think about the issues that might come before them.

It must be remembered, however, that sitting judges have stated that, when relevant at all, personal views are not nearly as important as they might appear to be during judicial elections. ${ }^{81}$ The actual benefit of such information is questionable at best, and, as the Mansfield example above suggests, the information might very well obscure more relevant criteria. More importantly, though, the marginal public benefit of knowing the views of judicial candidates simply does not justify the costs to judicial impartiality discussed in Part II.A.

\section{The Voters Need the Information}

Opponents of speech restrictions argue that the current system of electing judges, in both partisan and nompartisan elections, leaves the voter relatively uninformed. ${ }^{82}$ Voter turnout is low-well below that of elections for the other governmental branches; lack of information is

${ }^{79}$ See Rowe, supra note 16, at 613-16 ("Because the only power the government has is delegated from the people themselves, the people have a right to know where judicial candidates stand on important issues."). This argument, it should be noted, assumes that "legal formalists" are not correct in their belief that a judge simply applies law to facts, with no regard for personal feelings or beliefs. At the other end of the continuum are "legal realists" who believe that judges decide outcomes according to their subjective opinions and use the law only to justify those results. While the proper conception of judges and judging has been the subject of much debate, the truth probably lies somewhere in the middle. See, e.g., Reynolds Cafferata, Note, A Proposal for an Empirical Interpretation of Canon 5, 65 S. CAL. L. REV. 1639, 1672-74 (1992); Rowe, supra note 16, at 609-10. Judges are not simply "fungible automatons" who mechanically apply law to facts. Id. at 613 . Nor is it reasonable to assume that judges simply rule according to their personal predilections.

It should also be noted that, although some commentators believe that the ABA's speech restrictions embody the views of the "legal formalists," see Cafferata, supra, at 1640; O'Hara, supra note 6, at 231-33; Rowe, supra note 16, at 608 , this unsupported assumption is not necessary to justify speech restrictions on judicial candidates. As noted earlier, this Comment does not argue that judges' personal views are irrelevant, but only that allowing candidates themselves to communicate those beliefs to the public creates unacceptable consequences.

${ }^{80}$ See MCFADDEN, supra note 2, at 85 (noting that in deciding some questions, to which "neither statute nor case law gives a firm answer," a judge must base the decision on other grounds, "each of which will be affected ... by the judge's legal and political views").

${ }^{81}$ See id. at 89.
See Snyder, supra note 13 , at 250. 
usually blamed for this voter apathy. ${ }^{83}$ The information deficiency can be traced to sparse media coverage of judicial elections and the fact that voters are apparently unwilling to educate themselves in any other way. Thus, either citizens do not vote at all, or they base their decision on factors such as partisan labels, name recognition or ballot position. ${ }^{84}$ Such ad hoc selection processes have prompted one commentator to argue that accountability is lost because voters have no relevant information to utilize in making their decision. ${ }^{85}$ One way to rectify this problem is to allow the candidates to talk about issues the voters are interested in-the substantive decisions that the candidates will be making as judges. While virtually no one asserts that candidates should be permitted to discuss specific cases, many believe that candidates should be allowed to discuss general topics such as abortion, gun control, violent crime and the death penalty-issues which often excite interest in other elections-because voter interest and knowledge would increase, as would accountability. ${ }^{86}$

Unfortunately, in order to increase voter interest, these commentators would be willing to sacrifice the integrity of the judicial system. While there is no reason unnecessarily to stifle interesting discussion in the context of judicial elections, the law must not allow speech that compromises the impartiality of the candidate. Furthermore, as Justice Hans A. Linde of the Oregon Supreme Court has noted, the qualities that are truly relevant in selecting a good judge are fairness, impartiality, conscientiousness, attentiveness, sobriety and courtesy. ${ }^{87}$

${ }^{89}$ See MCFADDEN, supra note 2, at 10. But see Croley, supra note 7, at 730-39 (arguing that judicial elections are becoming more salient).

84 See CARP \& STIDHAM, supra note 6, at 243.

Voters may know whom they prefer for president or member of Congress or state senator, but when presented with a long list of persons running for state judgeships, they often resort to the method used for so long by the grandmother of one of the authors: "I voted for the men who had honest-sounding names."

Id.; see also MCFADDEN, supra note 2, at 10 (stating that voters often rely on partisan labels or, barring that, "whatever guidance they can [find]" (citation omitted)).

${ }^{85}$ See MCFADDEN, supra note 2, at 10 ("Judicial elections promise accountability, but that promise remains unfulfilled, and elections lose their ostensible justification, when the voters have no meaningful information upon which to base their choices."). While the idea of what judges should be accountable for is a slippery one, see supra Part II.B, it must be conceded that any form of accountability is undermined by a lack of interest.

${ }^{86}$ See Snyder, supra note 13 , at 250 ; O'Hara, supra note 6, at 230; see also Rowe, supra note 16 , at $625-26$.

${ }^{87}$ Justice Linde stated:

"Judicial accountability" has a virtuous ring to it, until one asks, "accountability" for what? For judging fairly and impartially, for conscientious 
These are the qualities that should be emphasized in judicial elections. ${ }^{\&}$ If other issues are discussed that garner more attention, such as a judge's personal views on controversial issues that might come before the court, that dialogue will detract from the factors which judges themselves have said are truly relevant.

Proscribing candidates from discussing their personal views on issues that will come before them, however, does not mean that elections must be boring, sporadically attended events. A candidate is free to discuss any of the issues discussed above regarding her qualifications or those of her opponent, court administration or anything else that neither commits nor appears to commit the candidate to issues that are likely to come before her in the future. ${ }^{89}$ The ABA's

attention to law and facts, for staying awake, sober and courteous to the parties, witnesses, and court personnel-in short, for performing according to the classic model of judging? Or does it mean accountability for decisions in controversial cases?

Hans A. Linde, The Judge as Political Candidate, 40 CLEv. ST. L. Rev, 1, 3 (1992). While the import of these factors varies depending on the particular court, particularly on whether the judge sits on a trial or appellate court, the fundamental concept-that the judge's particular views should not be discussed-is constant.

${ }_{B 8}$ The Kansas Supreme Court has endorsed such a position:

[U]nless the [judicial] election is to be a pure popularity contest based on name recognition alone, the only legitimate area for debate is the relative qualifications of the candidates. In our view the health, work habits, experience and ability of the candidates are all matters of legitimate concern to the electorate who must make the choice.

MCFADDEN, supra note 2, at 81 (quoting In re Baker, 542 P.2d 701, 705 (Kan. 1975)).

${ }^{89}$ MCFADDEN, supra note 2, at 91 . McFadden used the case of In re Baker, 542 P.2d 701 (Kan. 1975), as an example of a campaign which would be not only permissible, but also interesting and relevant. Baker involved a judicial race in Kansas governed by a much stricter rule than I propose in Part IV. See MCFADDEN, supra note 2, at 91. McFadden writes:

As a candidate, Judge Baker faced an incumbent who had suffered a heartattack, and who consequently had been working less tha[n] full-time. Judge Baker promised that "I can and will improve the quality and quantity of work that is presently required in the District Court." More specifically:

1. Jury trials and all other court business shall commence at 9:00 a.m. of a given day.

2. There will be no unnecessary delays or unnecessary recesses merely for the benefit of court officers or lawyers.

3. Business will be expedited in such a manner as to give full and proper consideration to all matters, and with diligence and dispatch.

4. The Court will return to serving the citizens instead of being a convenience to lawyers.

The sound track to one of Judge Baker's television commercials featured an empty judge's chair, a ticking clock, and the announcement, "Justice delayed is justice denied! Let's put our Courts on a full time status, Robert Baker will be a full time judge."

Id. (endnotes omitted). Judge Baker was successful in defeating the incumbent, and 
Special Committee on Evaluation of Judicial Performance, for example, has delineated eight criteria for the evaluation of sitting judges: (1) integrity; (2) knowledge and understanding of the law; (3) communication skills; (4) preparation, attentiveness and control over proceedings; (5) managerial skills; (6) punctuality; (7) service to the legal profession and the public; and (8) effectiveness in working with other judges. ${ }^{90}$

Another legitimate topic of discussion is what Stephen Carter has termed the candidate's "moral universe." The relevant question, according to Carter, "is not what sort of theory the nominee happens to indulge but what sort of person the nominee happens to be. ${ }^{92}$ Thus, "it is far less useful to know that a nominee has ruled that private clubs violate no constitutional provisions when they discriminate against non-whites than to know whether the nominee has belonged to a club with such policies." ${ }^{93}$ In the end, according to Carter, what will best serve the public interest is a judge with exceptional character and integrity rather than one whose views on certain issues coincide

the Kansas Supreme Court held his statements to be appropriate promises relating to the "faithful performance" of judicial duties. See In re Baker, 542 P.2d at 705; MCFADDEN, supra note 2, at 91. Putting aside the question of the propriety of such an advertisement, the example demonstrates that it is certainly possible for a candidate limited by a speech restriction to provide the voters with information "beyond his name, rank, and serial number." Buckley v. Illinois Judicial Inquiry Bd., 997 F.2d 224, 227 (7th Cir. 1993).

The American Bar Association has also endorsed the campaigning on such issues: "What kind of campaign may the candidate for judicial office conduct? He cannot campaign on a platform of partiality for specific persons or groups, nor can he commit himself in advance on disputed legal issues .... He can campaign on the basis of ability, experience, and record." E. WAYNE THODE, REPORTER'S NOTES TO CODE OF JUDICIAL CONDUCT 98 (1973).

${ }^{90}$ See MCFADDEN, supra note 2, at 71 (citing ABA Special Comm. on Evaluation of Judicial Performance, GUIDELINES FOR THE EVALUATION OF JUDICIAL PERFORMANCE, 920 (1985)).

${ }^{91}$ See STEPHEN L. CARTER, THE CONFIRMATION MESS 151 (1994).

[H] ow can the Senate carry out its responsibility to give voice to the deepest values and aspirations of the American people, while at the same time not compromising the necessary independence of the Justices? The answer may be to undertake what members of the Senate seem mysteriously reluctant to do-to try to get a sense of the whole person, an impression partaking not only of the nominee's public legal arguments, but of her entire moral universe.

Stephen Carter, The Confirmation Mess, 101 HaRV. L. REv. 1185, 1198 (1988). Carter formulated his proposal for use in the context of Supreme Court nominations. This Comment specifically discusses non-election situations, infra, in Part V. The entire Comment, though, is applicable to non-election situations.

92 CARTER, supra note 91 , at 151 .

${ }^{93}$ Id. at 152. 
with those of the majority. ${ }^{94}$ Such an approach not only allows for legitimate differentiation among candidates, but also permits the selecting power to make an informed decision that does not undermine judicial impartiality.

In addition to promoting certain avenues for discussion, voter interest can be increased more directly. Sarah Mathias, for example, has proposed a number of ways to enhance voter interest. ${ }^{95}$ Among other reforms, Mathias recommends "meet-the-candidate" programs, distribution of voters' pamphlets, the publication of judicial performance evaluations and bar polls, and the encouragement of media coverage of elections. ${ }^{96}$ The implementation of only a few of these suggestions might alleviate many of the concerns of speech restriction opponents. $^{.7}$

It should also be reemphasized that this Comment does not suggest that a candidate's views on issues that may come before her should never be discussed, but only that the candidate herself should not discuss her views, as that activity is what brings about the harms discussed above. ${ }^{98}$

Judicial elections, however, are simply not the same as elections for other governmental branches. They will not and should not mimic other types of elections in all respects. A judge's job requires a different set of qualities from those sought in traditional elections, and judicial impartiality should not be sacrificed to achieve a better turnout. Legislators are elected to act upon their convictions. Judges, however, must sit as neutral arbiters. While their convictions are important, the most relevant qualities are those that bear upon the fairness of the judicial process.

\section{Speech Restrictions Are Unnecessary}

\section{a. Recusal}

One commentator has suggested the possibility of recusal in the situation where a judge has previously made a public comment that prejudices or appears to prejudice her with respect to an issue then

${ }^{94}$ See id.

95 See MATHIAS, supra note 9, at 18-27.

96 Id.

${ }^{97}$ Professor Stephen Croley, however, asserts that voter interest in judicial elections is increasing without specific efforts in this regard. See Croley, supra note 7, at 73339.

${ }^{98}$ See supra Part II.A. 
before her. ${ }^{90}$ This commentator argues that speech restrictions reflect a deep mistrust that the candidate will not recuse herself when appropriate. ${ }^{100}$ Relying upon recusal alone, however, will not solve the problem.

First, such a judge might very well not recuse herself because she doesn't think that she will be influenced by her previous comments, may not know that she will be influenced, or does not care that she will be influenced. The third possibility is particularly likely, as her announcement suggests that she has strong feelings about the issue and will probably want to stay a part of the case if she can.

Second, a judge considering recusal in such a situation might feel pressured not to do so for fear that the public might view a recusal as reneging on her promise. For example, assume a judge had been elected following her statement that she had "never written an opinion reversing a rape conviction." ${ }^{101}$ If the judge were to recuse herself from a rape case on appeal, those who voted for her might very well view the decision as a breach of her implicit promise to be tough on rape defendants. The voters might then consider the judge untrustworthy and vote against her in the next election because the judge did not "deliver." Knowing this potential consequence, the judge might be reluctant to recuse herself.

Third, even if a judge were forced to recuse herself, if judicial candidates were permitted to discuss their beliefs on issues that might come before them, it is likely that every judge's views on important issues would be known. Even if there were no disagreement regarding the issue during the elections-for example, if all candidates promised to be tough on crime-the problem would still exist because all the candidates have made an implicit promise and are therefore subject to the pressures which accompany such a commitment.

Fourth, why should we permit a judicial candidate to imply that she will act a certain way, if by so doing she prohibits herself from carrying through on the promise? If the judge will recuse herself from a pertinent future case, then the campaign statement should be proscribed simply because it will mislead voters into believing that the

99 See Scott Robert Brown, Note, Deters v. Judicial Retirement and Removal Commission: Free Speech and the Appearance of Judicial Impartiality, 22 N. KY. L. REV. 497, 53639 (1995) (discussing a case in which a judicial candidate had publicly announced his pro-life stance on abortion).

${ }^{100}$ See id.

${ }^{101}$ Buckley v. Illinois Judicial Inquiry Bd., 997 F.2d 224, 226 (7th Cir. 1993); see also discussion, infra, Part III.A.4.b. 
candidate's view on that issue was a relevant voting consideration.

Finally, even if the candidate herself is not at all affected by her earlier campaign statements, and thus chooses not to recuse herself, this does not eliminate the problem of an appearance of partiality. This harm can be just as great as actual partiality. The judge might then recuse herself solely on the basis of this appearance, but the frequency with which recusals might occur illustrates the potentially tremendous systemic burden such a practice could create.

\section{b. The Public Can Figure It Out}

Another argument against speech restrictions is that, absent a restriction, the public is capable of sorting through the mess of campaign comments to separate the relevant from the irrelevant. ${ }^{102}$ While this may be true of some voters, it seems implausible that the majority of voters will interpret a campaign statement that "I will be tough on rapists," to really mean "I think that society should be tough on rapists, but I will look at each case impartially and reach a fair and just verdict based on the evidence and the law and not my personal beliefs." Such an idea verges on the absurd when one looks at the types of campaigns that have been conducted in the past. One good example is a 1984 race for a seat on the Supreme Court of Louisiana:

[A] candidate ... ran an advertisement against his incumbent opponent, Justice John Dixon. A large dagger ran along the left-hand side of the ad, and the headline blared: "JOHN DIXON DOESN'T THINK 20 STAB WOUNDS ARE ENOUGH." Justice Dixon had dissented in an opinion upholding a death sentence in a case where the victim had been stabbed twenty times. The ad continued: "On appeal to the Louisiana Supreme Court, six Justices agreed with the death sentence. ONLY JOHN DIXON DIDN'T .... HE DIDN'T THINK MORE THAN 20 TIMES WAS ENOUGH TO JUSTIFY THE DEATH PENALTY. WHAT ABOUT YOU? THERE COMES A TIME TO DRAW THE LINE. THE TIME IS NOW. ${ }^{103}$

It would be disingenuous at best to suggest that a voter reading that advertisement would not think that the campaigner was pledging to uphold death penalty sentences against individuals who were convicted of stabbing a person more than twenty times. ${ }^{104}$

102 See Brown, supra note 99 , at 538-39.

103 See MCFADDEN, supra note 2, at 69 (endnotes omitted).

104 Another telling example is the campaign to remove Tennessee Supreme Court Justice Penny White:

[T] he Tennessee Conservative Union sent out a letter that opened with the following description of crimes committed by Richard Odom: 


\section{Previously Proposed SPEech Restrictions}

\section{A. The American Bar Association's Speech Restrictions}

\section{The 1924 Canons of Judicial Ethics}

In 1924, the ABA, "mindful that the character and conduct of a judge should never be objects of indifference, and that declared ethical standards tend to become habits of life," ${ }^{105}$ formulated the Canons of Judicial Ethics ("1924 Canons"). The ABA created the 1924 Canons to "set forth its views respecting those principles which should govern the personal practice of members of the judiciary in the administration of their office." 106 The 1924 Canons contained the first $A B A$ restriction on judicial campaign conduct:

A candidate for judicial position should not make or suffer others to make for him, promises of conduct in office which appeal to the cupidity or prejudices of the appointing or electing power; he should not announce in advance his conclusions of law on disputed issues to secure class support, and he should do nothing while a candidate to create the impression that if chosen, he will administer his office with bias, partiality or improper discrimination.

Seventy-eight-year-old Ethel Johnson lay dying in a pool of blood. Stabbed in the heart, lungs, and liver, she fought back as best she could. Her hands were sliced to ribbons as she tried to push the knife away. And then she was raped. Savagely.

... But her murderer won't be getting the punishment he deserves. Thanks to Penny White.

Bright, supra note 7, at 168 . Following this was a Republican party mailing that described Odom's case as follows: "Richard Odom was convicted of repeatedly raping and stabbing to death a seventy year old Memphis woman. However, Penny White felt the crime wasn't heinous enough for the death penalty-so she struck it down." Id. at 169. Neither mailing revealed that

Odom's case was reversed because all five members of the Tennessee Supreme Court agreed that there had been at least one legal error that required a new sentencing hearing. ... Indeed, the remand for a new sentencing hearing ... made it clear that the court did not find the death penalty inappropriate for Odom. White did not write the majority opinion, a concurring opinion, or a dissenting opinion. Yet Tennessee voters were led to believe that she had personally struck down Odom's death penalty because she did not think the crime was "heinous enough."

Id.
105
106
CANONS OF JUDICIAL ETHICS pmbl. (1924).
Id.
${ }^{107} I d$. at Canon 30. 
2. The 1972 Code of Judicial Conduct

In 1972, the ABA House of Delegates replaced the 1924 Canons with the Code of Judicial Conduct ("1972 Code"). ${ }^{108}$ Canon 7 of the 1972 Code regulates the political activities of judges and judicial candidates. Canon $7 \mathrm{~B}(1)(\mathrm{c})$, in particular, states that a candidate for judicial office "should not make pledges or promises of conduct in office other than the faithful and impartial performance of the duties of the office; announce his views on disputed legal or political issues; or misrepresent his identity, qualifications, present position, or other fact." $10 \mathrm{~s}$

\section{The 1990 Model Code of Judicial Conduct}

In 1990, the $\mathrm{ABA}$ amended the 1972 Code and promulgated the Model Code of Judicial Conduct ("1990 Code"). ${ }^{110}$ Though the 1990 Code was based on the 1972 Code, "I the 1990 Code contained many substantial changes, perhaps the greatest of which involved the old Canon 7. Due to the consolidation of other canons, the ABA moved that controversial provision to Canon 5 and reworded the speech restriction to require that candidates for judicial office

(d) shall not:

(i) make pledges or promises of conduct in office other than the faithful and impartial performance of the duties of the office;

(ii) make statements that commit or appear to commit the candidate with respect to cases, controversies or issues that are likely to come before the court; or

(iii) knowingly misrepresent the identity, qualifications, present position or other fact concerning the candidate or an opponent.

While the "pledges and promises" clause remained unchanged, the $\mathrm{ABA}$ made two major changes to the rule. First, it replaced the "announce" clause of old Canon 7 with a "make statements" clause which makes no mention of "disputed political or legal issues."

103 See E. WAYNE THODE, AMERICAN BAR ASS'N, AMERICAN BAR FOUNDATION REPORTER'S NOTES TO CODE OF JUDICIAL CONDUCT 1 (1973).

${ }_{109}$ CODE OF JUDICIAL CONDUCT Canon 7B(1) (c) (1972).

${ }^{110}$ See LIṢA L. MiloRd, THE DEVELOPMENT OF THE ABA JUdiCIAL Code v (1992).

"II Id.

112 MODEL CODE OF JUDICIAI CONDUCT Canon 5A(3) (d) (1990).

${ }^{115}$ While the language of the restriction also was altered from the permissive 
Second, the "make statements" clause was limited by the "commit or appear to commit" language. The ABA effected these changes because the older rule was viewed as an excessive infringement of candidates' First Amendment rights, ${ }^{114}$ and because the 1972 version of the rule "could not be practicably applied in its literal terms."115 Unlike Canon 7, Canon 5 also contains written commentary designed to help interpret the rule.

\section{The Constitutionality of the ABA Restrictions ${ }^{116}$}

\section{a. Decisions Upholding Canon $7 B(1)(c)$}

Stretton v. Disciplinary Board of the Supreme Court of Pennsylvania ${ }^{117}$ currently stands as the leading case upholding the constitutionality of Canon 7B(1)(c). In Stretton, Samuel Stretton, a judicial candidate for Pennsylvania's Court of Common Pleas, challenged Canon 7 of Pennsylvania's Code of Judicial Conduct. ${ }^{118}$ Stretton claimed that the restriction chilled his First Amendment right to campaign by limiting the subjects about which he could speak. The topics that he wished to discuss included the fact that all of the current Court of Common Pleas judges in the county were Republicans, the need for judges with an "'activist' view," criminal sentencing, his qualifications and those of his opponent, the importance of the right to privacy, and administra-

\footnotetext{
"should" to the mandatory "shall," this in reality had little effect, as the ABA had enforced Canon $7 \mathrm{~B}(1)(\mathrm{c})$ as though it contained the compulsory language. See Mark R. Riccardi, Code of Judicial Conduct Canon $7 B(1)(c)$ : An Unconstitutional Restriction on Frea dom of Speech, 7 GEO. J. LEGAL ETHICs 153, 156 (1993) ("While the canon couches the restrictions in permissive terms, it is clear that compliance is meant to be compulsory.").

${ }^{115}$ MILORD, supra note 110, at 50; see also American Bar Ass'n Standing Comm. on See the discussion of the cases regarding the constitutionality of Canon 7, infra, Ethics and Professional Responsibility and Judicial Code Subcomm., Draft Revisions to the ABA Code of Judicial Conduct 56 (1989) (stating that the "announce" clause "was an overly broad restriction on speech").

${ }^{116}$ This Section analyzes only federal decisions and state supreme court decisions. There have been numerous other decisions involving these $A B A$ restrictions both by lower state courts and state administrative bodies. See, e.g., James J. Alfini \& Terrence J. Brooks, Ethical Constraints on Judicial Election Campaigns: A Review and Critique of Canon 7, $77 \mathrm{KY}$. L.J. 671, 687-94 (1988-1989) (examining the interpretation of Canon $7 \mathrm{~B}(1)(\mathrm{c})$ restrictions by state regulatory bodies).

117944 F.2d 137 (3d Cir. 1991).

118 See id. at 139 (noting that the plaintiff contended "that his ability to campaign for the position was impeded by the limitations imposed by the Code of Judicial Conduct"). Pennsylvania's Canon 7B(1) (c) is identical to the ABA's 1972 Canon 7B(1) (c). See id. at 141.
} 
tive changes. ${ }^{11}$

The district court, finding the restriction to be overbroad, struck down Canon $7 \mathrm{~B}(1)$ (c) as unconstitutional. ${ }^{120}$ In doing so, the district court rejected a narrower construction urged by the defendants that the restriction prohibited a candidate only from announcing a position on an issue that may later come before the court. ${ }^{121}$

The Third Circuit agreed with the reasoning of the district court as to the existence of a compelling state interest but reversed the district court's rejection of the defendant's limiting construction of Canon $7 \mathrm{~B}(1)(\mathrm{c}) .{ }^{122}$ The court noted that while "[s]peech uttered as part of a campaign for public office directly and unmistakably invokes the protection of the First Amendment," this dialogue may be regulated by the government. ${ }^{123}$ The court asserted that such a regulation compels a balancing of the interests of the individual and those of the government which "requires the state to establish a compelling interest and the restrictions to be narrowly tailored to serve that interest." ${ }^{124}$ The court stated that there could "be no question" that the integrity of a state's judiciary serves a compelling interest, and also that Canon $7 \mathrm{~B}(1)(\mathrm{c})$ advances that interest. ${ }^{125}$

119 See id. at 139.

120 See id. at 140 .

${ }^{121}$ See id. The trial court's decision not to read beyond the wording of the statute is consistent with the approach followed by the Seventh Circuit in Buckley v. Illinois Judicial Inquiry Board, 997 F.2d 224 (7th Cir. 1993), discussed, infra, Part III.4.b.

${ }^{122}$ See Stretton, 944 F.2d at 141-43. The court asserted that "adopting a restrictive interpretation is reasonable in light of the state's interests." Id. at 143.

${ }^{123}$ See id. at 141.

${ }^{124} I d$. (footnote omitted). The court took this test from the Supreme Court's opinion in Brown v. Hartlage, 456 U.S. 45, 53-54 (1982) ("[T] surely requires that the restriction be demonstrably supported by not only a legitimate state interest, but a compelling one, and that the restriction operates without unnecessarily circumscribing protected expression."), discussed, supra, Part I.

${ }^{125}$ See Stretton, 944 F.2d at 142 . In reaching this conclusion, the court relied upon two Supreme Court decisions, Landmark Communications., Inc., v. Virginia, 435 U.S. 829, 848 (1978) (Stewart, J., concurring) ("There could hardly be a higher governmental interest than a State's interest in the quality of its judiciary."), and Cox $v$. Lousisiana, 379 U.S. 559, 565 (1965) (" $[\mathrm{A}]$ State may... properly protect the judicial process from being misjudged in the minds of the public." ${ }^{n}$, as well as the Fifth Circuit decision of Morial v. Judiciary Comm'n, 565 F.2d 295, 302 (5th Cir. 1977) ("The state's interest in ensuring that judges be and appear to be neither antagonistic nor beholden to any interest, party, or person is entitled to the greatest respect."). The Stretton court further stated that

[i]f judicial candidates during a campaign prejudge cases that later come before them, the concept of impartial justice becomes a mockery. The ideal of an adjudication reached after a fair hearing, giving due consideration to the arguments and evidence produced by all parties no longer would apply and 
The court next turned to the scope of the restriction. As the Pennsylvania Supreme Court had not yet interpreted the rule, ${ }^{126}$ the court was forced to predict how that state court would have construed the regulation. ${ }^{127}$ The court determined that the Supreme Court of Pennsylvania would have limited the rule to apply only to issues likely to come before the candidate's court. ${ }^{128}$ In coming to this conclusion, the court noted that "every reasonable construction must be resorted to, in order to save a statute from unconstitutionality"'; ${ }^{21}$ that the Pennsylvania Supreme Court had narrowed statutes in the past; that such a construction would be consistent with other sections of the code; and that the defendants would be bound by their asserted position in the future. ${ }^{130}$ The court found the narrowed restriction to be constitutional as it did not "unnecessarily circumscribe protected speech."131 Importantly, this limited interpretation, according to the defendants, would not prohibit discussion of any of the plaintiff's proposed topics. ${ }^{132}$

In a case very similar to Stretton, the United States District Court for the Southern District of Ohio upheld the Ohio version of Canon $7 \mathrm{~B}(1)(\mathrm{c}) .{ }^{133}$ As in Stretton, the district court narrowed a rule that had not yet been interpreted by the Ohio Supreme Court. Similarly, the district court found that the state had demonstrated a compelling governmental interest in preserving the integrity of the state judiciary. ${ }^{134}$

\section{b. Decisions Striking Down Canon $7 B(1)(c)$}

Buckley $v$. Illinois Judicial Inquiry Board ${ }^{135}$ is the leading case striking

\footnotetext{
the confidence of the public in the rule of law would be undermined. Stretton, 944 F.2d at 142.

${ }^{126}$ See Stretton, 944 F.2d at 140.

${ }^{127}$ See id. at 143 .

128 See id. at 144 (" $[W]$ e predict that the Supreme Court of Pennsylvania would read Canon $7(B)(1)(c)$ to mean that 'disputed legal or political issues' refers only to those issues that are likely to come before the court.").

199 See id. at 144 (quoting Edward J. DeBartolo Corp. v. Florida Gulf Coast Bldg. \& Constr. Trades Council, 485 U.S. 568, 575 (1988) (citation omitted)).

${ }^{130}$ See id.

131 Id. at 142.

132 See id. at 142-43. In Part III.B.2, I argue that such an interpretation of a narrowed restriction must be modified to preserve the rule's effectiveness.

${ }^{193}$ See Berger v. Supreme Court, 598 F. Supp. 69 (S.D. Ohio 1984), affd mem., 861 F.2d 719 (6th Cir. 1988).

${ }^{134}$ See id. at 75 ("The Court believes that even under a standard of strict scrutiny, the state's regulation is necessary to achieve a compelling state interest.").

${ }^{135} 997$ F.2d 224 (7th Cir. 1993).
} 
down a version of Canon 7. It is the only Court of Appeals decision, other than Stretton, to deal with the constitutionality of state judicial campaign speech restrictions. In Buckley, the Seventh Circuit consolidated two cases for review. In the first case, Robert Buckley, a justice of the Appellate Court of Illinois, sought to invalidate a finding by the State's Judicial Inquiry Board that he had violated Rule $67 \mathrm{~B}(1)(\mathrm{c}) .^{190}$ While campaigning for a seat on the Supreme Court of Illinois, Buckley had circulated literature which stated that "he had 'never written an opinion reversing a rape conviction." 137 The Board brought charges against Justice Buckley presumably because it deemed his statement to be an implied promise to use a higher standard of proof with respect to rape cases. ${ }^{138}$ In the second action, Anthony Young, a former member of the Illinois legislature who had been elected to a state trial court position, sued alleging that the Rule prevented him from speaking on topics which were of interest to the electorate, including "capital punishment, abortion, the state's budget, and public school education." 139

The district court, following the Stretton and Berger decisions, upheld a magistrate judge's interpretation of the rule "limiting its scope to statements made on issues which are likely to come before the judicial candidate when sitting as a judge" and therefore found the rule to be constitutional. ${ }^{140}$

The Seventh Circuit Court of Appeals, Judge Posner writing, found this to be an unacceptable interpretation. ${ }^{141}$ The court began by recognizing the competing interests of free speech and the integrity of the judiciary, stating that "only a fanatic would suppose that

${ }^{196}$ See id. at 226. Illinois Supreme Court Rule $67 \mathrm{~B}(1)(\mathrm{c})$ is identical to Canon $7 \mathrm{~B}(1)(\mathrm{c})$, except that it also includes a proviso:

[A] candidate, including an incumbent judge, for a judicial office filled by election or retention ... should not make pledges or promises of conduct in office other than the faithful and impartial performance of the duties of the office; announce his views on disputed legal or political issues; or misrepresent his identity ... or other fact; provided, however, that he may announce his views on measures to improve the law, the legal system, or the administration of justice, if, in doing so, he does not cast doubt on his capacity to decide impartially any issue that may come before him.

Id. at 225 (quoting ILL. SUP. CT. R. 67B(1)(c)) (omissions in original).

197 Id. at 226.

${ }^{133}$ See id.

139 Id.

140 Buckley v. Illinois Judicial Inquiry Bd., 801 F. Supp. 83, 95, 102-03 (N.D. Ill. 1992), rev'd, 997 F.2d 224 (7th Cir. 1993).

14 See Buckley, 997 F.2d at 230. 
one of the principles should give way completely to the other."142 The court concluded that Rule $67 \mathrm{~B}(1)(\mathrm{c})$, however, attempted to do just that by eliminating the possibility of a commitment or the appearance of a commitment "in the most comprehensive fashion imaginable," rather than by limiting the rule's application to "pledges or promises to rule a particular way in particular cases or classes of case." court noted that while in general an overinclusive rule is not unconstitutional, "when an overinclusive rule has the effect, and it is fair to say the calculated effect, of greatly curtailing an important part of the speech 'market,' the rule is deeply problematic."144 The court also rejected the State's argument that the rule's proviso-which allowed a candidate to "announce his views on measures to improve the law, the legal system, or the administration of justice, if, in doing so, he does not cast doubt on his capacity to decide impartially any issue that may come before him"145 - sufficiently confined the scope of the rule. ${ }^{146}$ The court found that by adding to the proviso the limitation that the candidate may not cast doubt on his ability to be impartial on any issue which may come before the court,

what is given with one hand is taken away with the other [as] [a]lmost anything a judicial candidate might say about "improv[ing] the law" could be taken to cast doubt on his capacity to decide some case impartially, unless he confined himself to the most mundane and technical proposals for law reform. ${ }^{147}$

Thus, the court found that the rule, unless narrowed, could not stand constitutional scrutiny as the least restrictive means available.

The court refused to circumscribe the restriction for two reasons. First, while the court found such an interpretation to be "both plausible and consistent with the policy of the Supreme Court of Illinois," the district court's interpretation did not sufficiently limit the rule, especially with respect to the "pledges and promises" clause, which it

142 Id. at 227 .

143 Id. at 228. 68 (1984)).

${ }^{144}$ Id. at 229 (citing Secretary of State v. Joseph H. Munson Co., 467 U.S. 947, 964

\footnotetext{
${ }^{145}$ ILL. SUP. CT. R. $67 \mathrm{~B}(1)$ (c).

146 See Buckley, 997 F.2d at 229.

147 Id. The court continued:
}

If instead he announced boldly that he did not think juries should be used in most civil cases, he could be thought to be casting doubt on his capacity to preside impartially at civil jury trials, to rule on motions for directed verdict in such trials, to conduct a fair jury voir dire, to administer the rules of evidence in jury trials, and to decide on proposed jury instructions.

Id. 
did not restrict at all. ${ }^{148}$ Second, the court stated that even though such a decision would be consistent with the jurisprudence of the State's highest court, "[i]t is not our proper business to patch up the rule-and it would be a patchwork job indeed, with the rule itself saying one thing and the judicial gloss on it another." ${ }^{\text {149 }}$ The court was further influenced by the fact that the ABA itself had abandoned its old rule. The court noted that the ABA's decision to enact the new Canon $5 \mathrm{~A}(3)$ (d) appeared to be an assertion that the new rule was substantively different; this constituted probative evidence that Rule $67 \mathrm{~B}(1)(\mathrm{c})$ did not mean the same thing as Canon $5 \mathrm{~A}(3)(\mathrm{d}) .{ }^{1.50}$

In coming to this conclusion, the Buckley court apparently viewed the Canon 5A(3)(d) (ii) "commit or appear to commit" clause as a constitutional alternative to the overbroad "announce" clause. The court stated that "[a] 'saving' construction which transformed the rule into the ABA Canon that we just quoted would cast us in the role of a Council of Revision empowered to make such changes in a proposed enactment, state or federal, as might be necessary to render it constitutional." ${ }^{151}$ Since interpreting the Illinois Rule to mean the same thing as Canon 5 would "save" it, it stands to reason that the Buckley court considered the Canon 5 clause to be constitutional.

At the end of its opinion, the court recognized its divergence from the Stretton opinion and attempted, albeit without much vigor, to distinguish the Third Circuit decision. The court first noted that the Stretton court's limiting language on Canon $7 \mathrm{~B}(1)$ (c) applied to the entire rule and not just the "pledges and promises" clause. More importantly, the Buckley court seemed to suggest that the Stretton court would have decided differently if it had been confronted with the Buckley fact pattern where a candidate was "condemned [for] so innocuous a statement as a candidate's report of his past record in ruling on a particular type of case." 152

Before Buckley, a number of federal district courts and state courts had either struck down Canon 7 or suggested that it was unconstitutional. In $A C L U$ v. Florida $\mathrm{Bar}^{153}$ the American Civil Liberties Union and John Roe, a candidate for judicial office in Citrus County, Flor-

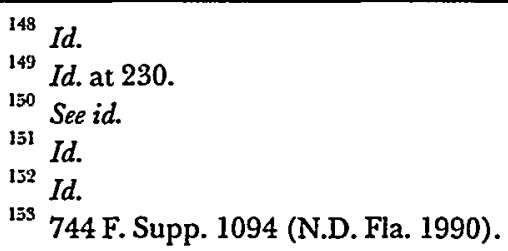


ida, challenged Florida's Canon $7^{154}$ on First Amendment grounds. The ACLU claimed that the restrictions kept the electorate from learning essential information about judicial candidates. Roe sought injunctive relief claiming that the Canon had chilled his speech and provided insufficient notice of what it proscribed. ${ }^{155}$ The district court recognized a compelling governmental interest in preserving the "integrity of the judiciary," but also found that a narrower restriction would still protect that interest. ${ }^{156}$ In addition, the court found that the State underestimated the electorate's ability to weigh relevant and irrelevant information. ${ }^{157}$ Finally, the court stated that since "judges routinely exercise their discretion within the confines of the facts and the law," the public had a substantial interest in knowing judicial candidates' views on political and legal issues, and that such views were not irrelevant. ${ }^{158}$

In J.C.J.D. v. R.J.C.R., ${ }^{159}$ the Kentucky Supreme Court considered the constitutionality of a speech restriction substantially similar to Canon $7 .^{160}$ The plaintiff in the case was then-Justice Combs who, during his campaign for a seat on the supreme court, had criticized the standard of review for workers' compensation claims, a state law which barred convicted felons from carrying handguns, and his opponent's decision in a personal injury case. ${ }^{161}$ Following these remarks, the Judicial Retirement and Removal Commission found that Justice Combs's statements had violated the statute by "clear and convincing evidence." 162 Relying upon Florida Bar, the Kentucky Supreme Court struck down the regulation because it was not the least restrictive means available to satisfy the asserted governmental interest. ${ }^{163} \mathrm{Al}$ -

154 FLA. CODE OF JUdICIAL CONDUCT Canon 7(B)(1)(c) (1982) ("A candidate, including an incumbent judge, for a judicial office that is filled either by public election between competing candidates or on the basis of a merit system election:... (c) should not make pledges or promises of conduct in office other than the faithful and impartial performance of the duties of the office; announce his views on disputed legal or political issues; or misrepresent his identity, qualifications, present position, or other fact.").

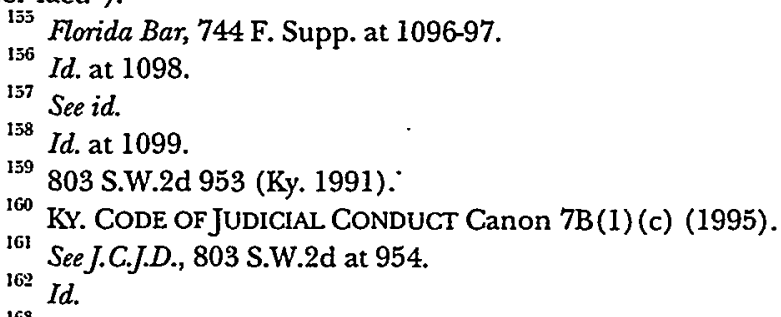

163 See id. at 956 ("To specifically prohibit [sic] this type of campaign conduct and avoid constitutional concerns, this Canon provision can be rewritten in a much narrower scope to outlaw discussion of pending or future litigation."). 
though the court recognized that Kentucky "has a compelling interest to protect and preserve the integrity and objectivity of the judicial system," it nevertheless determined that the rule also prohibited legitimate speech and thus was unconstitutionally overbroad. ${ }^{164}$

\section{c. Decisions Upholding the Constitutionality of Canon $5 A(3)(d)$}

To date, Ackerson v. Kentucky Judicial Retirement $\mathcal{E}$ Removal Commission $^{165}$ is the only federal court decision to consider the constitutionality of a version of Canon 5A(3)(d). In Ackerson, a candidate for the Kentucky Court of Appeals challenged Kentucky's new Canon $7 B(1)(c)$, which directly parallels the ABA's Canon $5 A(3)(d) .{ }^{166}$ The plaintiff claimed that the restriction was unconstitutionally overbroad, was a prior restraint, and was so vague that it chilled his First Amendment right to discuss certain court administrative matters and to comment on "general legal issues," both of which would fall under the rule's ban on legal or political issues "that are likely to come before the court." ${ }^{\text {167 }}$

The district court reiterated the two-pronged "compelling state interest"/"narrowly tailored" test and found that while there was a compelling state interest in an impartial judiciary, this interest did not extend to prohibiting a judicial candidate from speaking on court administrative matters. ${ }^{168}$ The court maintained, however, that this finding did not require striking down the entire statute. ${ }^{169}$ Instead, the court tailored its remedy and enjoined the Kentucky Judicial Retirement and Removal Commission from enforcing the regulation with respect to campaign commitments involving court administrative matters. ${ }^{170}$ Thus, the candidate was free to discuss "an alleged backlog of cases, methods of assignment of cases, numbers of pending cases, hiring and firing of employees, and administrative expenses relating

IG4 Id. at 956-57.

163776 F. Supp. 309 (W.D. Ky. 1991).

${ }^{160}$ See id. at 311 (quoting the language of the Kentucky rule, which is very similar to the ABA's Canon $5 \mathrm{~A}(3)(\mathrm{d})$ ).

167 Id.

${ }^{163}$ See id. at 313-14 (asserting that "[t]here is no compelling state interest which justifies limiting a judicial candidate's speech on court administrative issues").

${ }^{169}$ See id. at 314. The court quoted Osborme v. Ohio, 495 U.S. 103 (1990): Even where a statute at its margins infringes on protected expression, "facial invalidation is inappropriate if the "remainder of the statute ... covers a whole range of easily identifiable and constitutionally proscribable ... conduct ...." Id. at 112 (quoting New York v. Ferber, 458 U.S. 747, 770 n.25 (1982)).

${ }^{170}$ See Ackerson, 776 F. Supp. at 315-16. 
to travel."171

The court held that the rule as applied to campaign promises regarding legal issues likely to come before the court, however, did pass constitutional scrutiny. In coming to this conclusion, the court first rejected the plaintiff's contention that the difficulty in determining what is likely to come before a court made the rule impermissibly vague. ${ }^{172}$ The court found that any chilling effect which the regulation had upon speech was consistent with the First Amendment because the interest in an impartial judiciary "is simply too great to allow judicial campaigns to degenerate into a contest of which candidate can make more commitments to the electorate on legal issues likely to come before him or her." 173

In Deters v. Judicial Retirement $\mathcal{E}^{2}$ Removal Commission, ${ }^{174}$ the Kentucky Supreme Court upheld the same statute at issue in Ackerson. ${ }^{175}$ The plaintiff in Deters had campaigned for a trial court position and had instructed his subordinates to place advertisements in two Kentucky newspapers which read: "Jed Deters is a Pro-Life Candidate."176 After the State's Judicial Retirement and Removal Commission censured Deters, he sought declaratory relief. ${ }^{177}$

The Deters court followed the Ackerson decision and found both that there was a compelling state interest and that the restriction was as narrowly tailored as possible. ${ }^{178}$ The court's handling of the plaintiff's claim that the issue of abortion was not one "likely" to come before the court, though, is noteworthy. The plaintiff relied on three facts: that no abortion cases had been adjudicated in the jurisdiction in over a decade; that the only two hospitals in the district did not perform abortions; and that there were no licensed abortion clinics in the district. ${ }^{179}$ The court determined, however, that the issue of abortion was likely to come before the plaintiff's court, because Kentucky

171 Id. at 311.

172 See id. at 314-15.

173 Id. at 315.

174873 S.W.2d 200 (Ky. 1994).

${ }^{175}$ See id. at 204-05. Deters is the only state supreme court decision-and Ackerson the only federal court decision-to consider the constitutionality of Canon $5 \mathrm{~A}(3)$ (d).

176 Id. at 201.

${ }^{177}$ See id.

${ }^{178}$ See id. at 204-05 ("[T]he Ackerson opinion holds, as do we, that there is a compelling state interest in ... limiting a judicial candidate's speech, because the making of campaign commitments on issues likely to come before the court tends to undermine the fundamental fairness and impartiality of the legal system.").

${ }^{179}$ See id. at 203. 
had a procedure whereby a minor could "petition a district court for an order permitting an abortion." ${ }^{, 180}$ In addition, the court found that Deters might very well be confronted with cases "involving abortion protests, including trespass, disorderly conduct, or assault," and that "district judges are often asked to serve as special judges in other counties where numerous abortion-related issues are pending before the court." ${ }^{\text {181 }}$ More importantly, however, the court found that Deters, in making his statement against abortion, had also committed himself on other issues which were likely to come before the court. ${ }^{182}$ The court noted the disciplinary commission's assertion that the "spro-life' movement is not limited to abortions but also deals with living wills and controversies involving removing tubes or respirators, which are "big issue(s) right now, something that might come before a Judge."' ${ }^{8 s}$ In coming to its conclusion, the court recognized the prejudicial potential of implicit promises which reach beyond the topic to which the candidate explicitly commits herself.

\section{Analysis of the Case Law}

\section{a. Canon $7 B(1)(c)$}

Absent a significant departure from the courts' current mode of analysis, it appears that preserving the impartiality of the judiciary will be found to satisfy the Supreme Court's requirement of a compelling state interest sufficient to allow infringement of a judicial candidate's First Amendment rights. ${ }^{184}$ It seems equally clear, however, that as written Canon $7 \mathrm{~B}(1)$ (c) is an unconstitutional restriction on free speech as it is not the least restrictive means available. While Stretton and Berger narrowed their respective speech restrictions to bring them into compliance with the First Amendment, the trend has been against such rewriting. ${ }^{185}$ The ABA itself recognized this, and its amendment of Canon 7 was designed to bring the restriction into

$180 \mathrm{Id}$.

$181 \mathrm{Id}$.

182 See id.

${ }^{183}$ Id. This Comment does not necessarily endorse this last finding by the Kentucky Supreme Court. It is questionable whether Deters could be said to have "committed" himself on these issues or to have made any "pledge or promise."

${ }^{184}$ Preventing a judicial candidate's comments from misleading the electorate could also be a compelling state interest. See discussion, supra, Part II.A.4.

${ }^{185}$ See cases, supra, Part III.A.4.b; see also Beshear v. Butt, 863 F. Supp. 913, 917 (E.D. Ark. 1994) (finding unconstitutional an Arkansas restriction substantially similar to Canon 7). 
conformance with the opinions of those courts which had struck down versions of the rule. ${ }^{186}$

\section{b. Canon $5 A(3)(d)$}

Although two decisions have upheld the constitutionality of Canon 5A(3) (d), the overbroad "pledges and promises" clause makes the continuation of this trend unlikely. ${ }^{187}$ The court in Buckley, particularly, pointed out the inadequacy of correcting only half the rule, as the district court judge had done in that case. ${ }^{188}$ Even in the two decisions upholding the Canon, the Ackerson court had to narrow substantially the "pledges and promises" clause to find the rule to be constitutional, ${ }^{189}$ while the Deters decision did not involve the "pledges and promises" clause and merely followed the Ackerson court's analysis with respect to the constitutionality of the rule. ${ }^{190}$

Another potential problem with Canon $5 \mathrm{~A}(3)$ (d) centers on the use of the word "likely," another carry-over provision from Canon $7 \mathrm{~B}(1)(\mathrm{c})$, and one which troubled the Buckley court. According to that court, "[ $t]$ here is almost no legal or political issue that is unlikely to come before a judge of an American court, state or federal, of general jurisdiction." ${ }^{191}$ Judge Posner went on to state that even the civil war in Yugoslavia, for example, would fall into such a classification. ${ }^{12}$

${ }^{186}$ See MILORD, supra note 110, at 50 (stating that the "Committee believed its revised rule to be more in line with constitutional guarantees of free speech").

${ }^{187}$ A number of books and law review articles support this view. See, e.g., MCFADDEN, supra note 2, at 70 (noting that courts require that "regulations be tailored narrowly to the purposes they seek to accomplish"); Robert M. Brode, Note, Buckley v. Illinois Judicial Inquiry Board and Stretton v. Disciplinary Board of the Supreme Court: First Amendment Limits on Ethical Restrictions of Judicial Candidates' Speech, 51 WASH. \& LEE L. REV. 1085, 1119-20 (1994) (finding that the clause "remains unconstitutional"); Brown, supra note 99, at 540 (arguing that Deters was wrongly decided); Rowe, supra note 16, at 623-24 (stating that the "pledges or promises clause is still unconstitutionally overbroad").

${ }^{188}$ See Buckley v. Illinois Judicial Inquiry Bd., 997 F.2d 224, 230 (7th Cir. 1993) (stating that "[i]t is not our proper business to patch up the rule").

${ }^{189}$ See Ackerson v. Kentucky Judicial Retirement \& Removal Comm'n, 776 F. Supp. 309, 313-16 (W.D. Ky. 1991).

${ }^{190}$ See Deters v. Judicial Retirement \& Removal Comm'n, 873 S.W.2d 200, 203-05 (Ky. 1994).

${ }^{191}$ Buckley, 997 F.2d at 229.

192 Judge Posner stated:

[W]e have cases in which Yugoslavs resist deportation to that nation on the ground that they face persecution from one or another side in that nation's multisided civil war; and some years ago the Illinois courts were embroiled in a custody fight involving a child who didn't want to return to the then Soviet Union with his Soviet parents. 
In coming to such a conclusion, however, Judge Posner interpreted "likely"193 to mean "possibly." It would, indeed, be impossible to say that no issue could possibly come before a court of general jurisdiction, but it is safe to say that the chances of a case involving the war in Yugoslavia coming before a given court in this country are not very high. ${ }^{194}$ This objection to the use of "likely," therefore, will probably not invalidate speech restrictions in the future.

\section{B. Other Proposals}

\section{State Restrictions}

Many states have reformulated their speech restrictions in response to the constitutional challenges discussed above. Kentucky, Arkansas and several other states have modeled their new restrictions on Canon 5 of the 1990 Code. $^{195}$ Others have developed their own derivatives of the 1972 Code. One example is Illinois, whose new Rule 67(A) states that

(3) A candidate for a judicial office:

(d) shall not:

(i) make statements that commit or appear to commit the candidate with respect to cases, controversies or issues within cases that are likely to come before the court; or

(ii) knowingly misrepresent the identity, qualifications, present position

\footnotetext{
Id.

193 The dictionary definition for "likely" is "possessing or displaying the qualities or characteristics that make something probable." THE AMERICAN HERITAGE DICTIONARY OF THE ENGLISH LANGUAGE 1042 (3d ed. 1994) (emphasis added).

194 Furthermore, "likeliness" does not, as at least one commentator has suggested, require an evaluation of statistical data. See O'Hara, supra note 6, at 227 . Instead, it seems clear that if there exists a significant chance that an issue will come before the court, the candidate should not express her views on it. While any standard has its gray area, a candidate who is genuinely unsure can simply ask the state's disciplinary commission whether her proposed speech would be in violation of the prohibition. Any benefit denied the electorate due to the inevitable chilling of some otherwise permissible candidate speech (i.e., the issue is not likely to come before the court, but the candidate refrains from speaking anyway) is negligible when compared to the overriding goal of judicial impartiality.

${ }^{193}$ See, e.g., ARK. CODE OF Judicial CONDUCT Canon 5 (1996); KY. CODE OF JuDICIAL CONDUCT Canon 5 (1996).
} 
or other fact concerning the candidate or an opponent. ${ }^{196}$

The Illinois rule, while using the same "statements" clause as the 1990 Code, completely eliminates the constitutionally problematic "pledges and promises" clause. In addition, the rule contains a limitation on the word "issues," restricting the regulation to "issues within cases." Although it has been argued that this limitation renders the rule less constitutionally suspect, ${ }^{197}$ Canon 5 should be similarly interpreted in that it applies only to issues which "are likely to come before the court." Logically, such issues would consist of "issues within cases."

The Illinois rule, however, does not solve all of the potential constitutional problems. It is still difficult to determine what conduct falls within the restriction's ambit. To whom, for example, does it have to appear that the candidate has committed herself on an issue which is likely to come before the court? The answer to this question will almost certainly depend upon who is evaluating the statement. Unless this is clarified, the rule is vulnerable to a charge of unconstitutional vagueness. ${ }^{198}$

Also, as will be discussed in the next Section, the interpretation of a rule is as important as its text. One commentator, at least, has argued that the language of the Illinois rule should be interpreted to limit the restriction to cases or controversies which are actually pending before the court. ${ }^{199}$ Such a circumscription of the rule's scope would severely hamper its effectiveness and leave a gaping hole in the protection afforded to judicial impartiality. ${ }^{200}$

Finally, some states have enacted speech restrictions not based on either version of the ABA code. Wisconsin, for example, has adopted a rule (the first sentence of which is based on the 1924 Canons) which states:

A judge who is a candidate for judicial office shall not make ... promises or suggestions of conduct in office which appeal to the cupidity or partisanship of the electing or appointing power. A judge shall not do ... anything which would commit the judge or appear to commit the

196 ILL. SUP. CT. RULE 67(A) (3) (d) (i)-(ii) (1996).

${ }^{197}$ See O'Hara, supra note 6, at 230 ("This modification may also sufficiently address ... the concern over the overbreadth of the prohibition of speech about 'issues' (...").

See Gentile v. State Bar, 501 U.S. 1030, 1048 (1991) (holding the Nevada Supreme Court's interpretation of a court rule unconstitutionally vague in its application to certain statements made by an attorney at a press conference).

${ }^{199}$ See O'Hara, supra note 6, at 230.

200 See infra notes 203-07 \& 214-17 and accompanying text. 
judge in advance, with respect to any particular case or controversy or which suggests that, if elected or chosen, the judge would administer his or her office with partiality, bias or favor. ${ }^{201}$

While this rule appears to address some of the overbreadth problems of the 1990 Canons, much depends-as with the Illinois ruleon subsequent interpretation. The meanings of "cupidity" and "partisanship" could render the rule either unconstitutionally overbroad or ineffectually underinclusive.

\section{Proposals by Commentators}

A number of commentators have proposed rules which may satisfy the constitutional hurales that the courts have erected. J. David Rowe has proposed a rule which, much like the Illinois rule, restricts the "pledges and promises" clause of the ABA's Canons and collapses the two clauses into one: "A candidate for judicial office shall not make pledges or promises of conduct while in office, nor any other statements that commit or appear to cornmit the candidate with respect to issues, cases, or contrcversies likely to come before the court." ${ }^{202}$

While this rule, like the state speech restrictions discussed above, does not fully address vagueness concerns, a more serious problem with the rule is not its language, but rather its proposed interpretation. According to Rowe, this rule would proscribe promises made with regard to identified cases, such as "Elect me, and I'll make sure that Mr. X's death sentence will not be overturned, ${ }^{, 203}$ or to specific groups, such as "Elect me, and I'll rule in favor of the Mine Workers' Union." It would not, though, restrict statements about general issues or classes of cases, such as those at issue in Buckley. ${ }^{204}$ Such an interpretation, however, fails to protect against the dangers of partiality and the appearance of partiality. ${ }^{205}$ Allowing declarations which, notwithstanding their generality, are implicit promises of conduct, ${ }^{206}$ does

${ }^{201}$ WIS. SUP. CT. R. 60.15 (1996).

${ }^{202}$ Rowe, supra note 16 , at 626 (explaining that his proposed rule incorporates his distinction between case-specific unprotected speech and more general protected speech).

${ }^{203} I d$. (internal quotations omitted).

${ }^{204}$ As discussed above, Buckley dealt with a candidate who stated that he had "never written an opinion reversing a rape conviction." Buckley v. Illinois Judicial Inquiry Bd., 997 F.2d 224, 225-26 (7th Cir. 1993).

${ }_{205}$ See supra Part II.A.1-2.

${ }^{206}$ In Buckley, the implicit promise was that the defendant would hold convicted rape defendants to a higher standard on appeal than other defendants. Buckley, 997 F.2d at 226. 
not fully safeguard judicial impartiality.

Matthew O'Hara's proposed rule simply states in the text of the rule what is implied by Rowe's rule:

A candidate for a judicial office shall not:

(i) make pledges or promises of conduct in office regarding any pending or impending proceeding before the candidate's court;

(ii) make statements that commit or appear to commit the candidate with respect to pending or impending cases or controversies that may reasonably appear likely to come before the court. ${ }^{207}$

In addition to limiting the rule to cases or controversies which are "pending or impending," the "statements" clause requires that cases must "reasonably appear likely" to come before the court. O'Hara included this language "explicitly [to] address the analysis of Buckley concerning the word "likely." ${ }^{208}$ As discussed above in connection with the Buckley case, however, such limiting language is unwarranted, as that court took an unnecessarily broad-and speech-restrictiveview of the word "likely." ing the meaning of "likely" could correct such a misconstruction. In any case, it is questionable whether O'Hara's addition of the word "reasonably" changes the analysis much, as presumably in interpreting the statute courts will measure the probability of a case or controversy reaching a particular court objectively. The most important feature of this proposed rule, however, is the limitation of the restriction to specific, identified cases. As O'Hara states, "although the candidate may not express a view on whether a specific defendant might receive the death penalty, he may express a view on capital punishment in general." ${ }^{210}$ Such an interpretation, as in Rowe's rule, still permits statements which could result in judicial partiality or the appearance of partiality.

\section{A CONSTITUTIONAL ALTERNATIVE TO THE ABA'S SPEECH RESTRICTIONS}

The First Amendment imposes two conditions on speech regulations. The first requirement is that there be a compelling state inter-

207 O'Hara, supra note 6, at 229 (footnotes omitted).

${ }^{208} I d$. (explaining that judges must rely on common sense to decide when an issue is likely to come before them).

${ }^{209}$ See supra Part III.A.4.b.

${ }^{210}$ O'Hara, supra note 6, at 230. 
est that supports the need to regulate speech. The case law supports the idea that the state's need for an impartial judiciary is a compelling interest. ${ }^{211}$ The second requirement is that the restriction must use the least restrictive means possible. ${ }^{212}$ Many current speech regulations violate this latter requirement.

Canon $5 \mathrm{~A}(3)$ (d) solves some of the problems of the original Canon $7 \mathrm{~B}(1)(\mathrm{c})$, but the remaining "pledges and promises" clause will likely lead any court which has struck down Canon $7 \mathrm{~B}(1)(\mathrm{c})$ to treat Canon $5 \mathrm{~A}(3)$ (d) similarly. ${ }^{213}$ An acceptable rule must, in some way, limit the "pledges or promises" clause. One way to accomplish this, as exemplified by the Illinois and Rowe rules, is to eliminate the clause altogether. This is an appropriate alteration. The harm which this clause attempts to avoid is partiality or the appearance of partiality by judges elected as a result of pledges, promises or statements made during their campaigns which commit or appear to commit them with respect to cases, controversies or issues which might come before them in the future. So long as the word "statements" includes "pledges or promises," the rule will proscribe pledges or promises which might bring a judge's impartiality into question.

Creating a constitutional rule, however, is only half the job. In addition, the rule must effectively deal with threats to judicial impartiality. A constitutional rule which accomplishes both goals might read:

A candidate, including an incumbent judge, for a judicial office shall not (i) make statements that a reasonable member of the relevant selecting body would believe commit or appear to commit the candidate with respect to cases, controversies or issues that are likely to come before the court; or (ii) knowingly misrepresent the identity, qualifications, present position or other facts concerning the candidate or an opponent.

This rule differs from other proposals in that it includes a "reasonable member" standard. The "reasonable member of the selecting body" standard is necessary to take into account implied promises and to decrease the vagueness of the restriction. The only

211 See supra Part III.A.4.c.

${ }^{212}$ See Brown v. Hartlage, 456 U.S. 45, 54 (1982) (requiring speech restrictions to "operate without unnecessarily circumscribing protected expression").

${ }^{213}$ The Buckley court suggested such a result when it rejected the district court's proposed limitation on Illinois Supreme Court Rule $67 \mathrm{~B}(1)(\mathrm{c})$-which would have reproduced exactly the ABA's Canon $5 \mathrm{~A}(3)(\mathrm{d})$ - -because such an interpretation did not restrict in any way "the 'pledges or promises' clause which is as overbroad as the 'announce' clause." Buckley v. Illinois Judicial Inquiry Bd., 997 F.2d 224, 229 (7th Cir. 1993). 
way to know whether a candidate has violated the rule-by making an implied promise to act in a particular manner-is to ask whether a reasonable person would have understood it as such.

The proposed interpretation of this rule, however, is more important than its text. As discussed above, states and commentators have suggested similar speech restrictions. They limit the application of their proposed rules, however, either to explicit promises to certain individuals or groups, ${ }^{214}$ or to comments on specific cases. ${ }^{215}$ General statements, such as the one in Buckley, however, would be legitimate "because they do not threaten either of the harms [impairing the judiciary's ability to exercise independent judicial review or to render impartial decisions] that the gag rule is designed to protect against."216 These interpretations, though, fail to consider the obvious dangers posed by implicit promises of conduct. General statements of a candidate's views which are really implicit commitments-such as Justice Buckley's statement that he had never written an opinion reversing a rape conviction-threaten judicial impartiality as much as explicit promises. If a reasonable member of the selective body, taking into account the context of the remark, would understand the statement to be an implied promise never to vote to reverse a rape conviction, the statement would constitute a real threat to judicial impartiality and should be proscribed. It is exactly that type of statement which destroys a judge's impartiality and impugns the integrity of the entire judicial system. Finally, it must be remembered that it is almost impossible to draw a line as to what constitutes an implied promise based on the words of the statement alone. Context is crucial. For example, the statement "I have spent the last twenty years as a prosecutor," has a very different meaning when given in response to a question about general qualifications to be a judge as opposed to a question about whether the candidate will be tough in rape cases.

\section{APPLICATION TO JUDICIAL APPOINTMENTS}

While this Comment has focused primarily on speech restrictions in the context of judicial elections, no such limitation governs the

${ }^{214}$ See Rowe, supra note 16 , at $625-26$.

215 See O'Hara, supra note 6, at 229.

${ }^{216}$ Rowe, supra note 16, at 625; see also Sholette, supra note 51, at 159 (finding that the Third Circuit's interpretation of Canon 7(B) (1) (c) "would ... permit discussion of ... more controversial topics ... such as a candidate's personal views on privacy, criminal sentencing and burdens of proof"). 
ABA's speech restriction contained in the 1990 Code, ${ }^{217}$ and none should apply to the above proposal. While undoubtedly there are differences between the two situations, most of the dangers of explicit or implicit campaign promises exist equally in appointment situations ${ }^{218}$ and justify speech restrictions in that setting as well.

The most significant distinction between the two situations is the lack of any sort of election in many appointment systems. An appointed judge does not become shackled by her earlier statements in the same manner as a judge who may face voter retribution in the next election. An appointed judge who makes prohibited comments might never feel pressured to comply with outside forces. ${ }^{219}$ In addition, while it is often argued that candidate comments mislead the public, an appointment system involves evaluation by arguably more sophisticated individuals such as legislators and executive branch officials. Such persons, the argument goes, are better equipped to distinguish between a candidate's views on certain issues and promises of conduct, knowing that the candidate will be governed by the law and the facts of the case. Some commentators, whether or not they support speech restrictions in the election context, feel that these considerations warrant allowing legislative and executive branch officials to inquire into the views of judicial candidates. ${ }^{20}$

The differences between elections and appointments do not, however, require such a conclusion. Although it is true that some of the quandaries that accompany speech in judicial elections do not exist in judicial appointments, many of the concerns discussed in Part II

217 See MOdel CODE OF JUdicial CONDUCT, at Terminology (1990) (defining "candidate" as "a person seeking selection for or retention in judicial office by election or appointment" (emphasis added)); CANONS of JUDICIAL ETHICS Canon 30 (1924) (applying the Canon's restrictions to election and appointment). But see CODE OF JUDICIAL CONDUCT Canon 7B(1) (1972) (applying the section to positions "filled either by public election between competing candidates or on the basis of a merit system election").

${ }^{218}$ These include merit selection systems, pure appointment systems and appointments followed by retention or elections.

${ }^{219}$ This situation may not arise where an initial appointment is followed by elections, such as when a candidate is appointed to fill an immediate vacancy or in a meritselection system. In such a situation, the possibility that the public will punish a candidate for not following through on her word still exists.

${ }_{220}$ See Arlen Specter, Concluding Address: On the Confirmation of a Supreme Court Justice, 84 Nw. U. L. REV. 1037, 1042 (1990) ("Given the importance of the Court and the historical record on executive selections of its nominees, it is not wise to limit public scrutiny."); Nina Totenberg, The Confirmation Process and the Public: To Know or Not to Know, 101 HARV. L. REV. 1213, 1220-23 (1988) (supporting the intense questioning of Robert Bork during his Supreme Court confirmation hearings and calling for such an inquiry into all judicial candidates). 
of this Comment are still implicated. The most important of these is the psychological commitment attending any statement regarding a candidate's views. While a senator might ask a Supreme Court nominee whether she believes that the Third, Fourth, Fifth and Ninth Amendments have a penumbra that protects an individual's right of privacy, what the senator is really asking (and what everyone knows the senator is really asking) is whether the nominee supports the opinion in Planned Parenthood of Southeastern Pennsylvania v. Casey. ${ }^{221}$ Unless the nominee refuses to answer, her response may be regarded as indicative of how she will vote in future abortion cases. In addition, as discussed earlier, even if the candidate had been completely ambivalent about the issue before answering, the candidate will forever after be biased toward her stated position. ${ }^{222}$

Such an implicit commitment is understood as such by all parties and the nominee may also consciously feel constrained by it in the future. In addition to the potential moral impulsion, the nominee faces the risk of public opposition if she makes a decision inconsistent with her expressed opinion. While the judge may not be subject to removal, no judge wants a reputation for untrustworthiness, especially when she is in the public eye. Such a danger is intensified if the nominee must actually face the electorate at some point, as in the case of merit selection.

Finally, even in the absence of the above concerns, such a situation still appears improper. The appointment of an individual because she has expressed how she will decide certain issues makes it appear as though the protections of the Constitution and the laws extend only as far as the legislature and/or the executive desire that they should.

\section{CONCLUSION}

When balancing the right to free speech against the maintenance of an impartial judiciary, there are fewer concrete answers than policy choices. The ABA and many commentators have attempted to balance these interests in a variety of ways, each with either constitutional or practical problems. The ABA speech restrictions are not narrowly tailored, and thus cannot withstand constitutional scrutiny under the

221 505 U.S. 833, 845-46 (1992) (reaffirming the central holding of Roe v. Wade, 410 U.S. 113 (1973), that a woman has a constitutional right to have an abortion before viability and to obtain it without undue interference from the state).

${ }^{222}$ See supra notes $41-47$ and accompanying text. 
Supreme Court's First Amendment jurisprudence. The interpretations of other, probably constitutional, restrictions will not adequately protect judicial impartiality.

In the end, the relevant question is: How will the public best be served? Arguably, the public will best be served by securing "the best judges possible."223 Selecting those judges with the best qualifications-not those whose ideologies happen to parallel the current majority's-accomplishes this goal. A system with no restrictions is ripe for potential abuse. No longer would selection processes be about which judge possesses the best qualifications or superior experience. Rather, they would be about which judge would satisfy the public's demand for tougher appellate review of convictions or which judge would read into the Constitution a privacy right to have an abortion. The system would suffer not only because the most able judges would not be selected, but also because the public perception of the impartiality of the judicial branch would deteriorate as rulings would appear to be motivated by political rather than legal considerations. Furthermore, the lack of impartial adjudicators would injure the interests of individual litigants, especially if their cases were highly publicized or happened to fall near an election.

While there are certainly many other concerns regarding judicial selection-including voter apathy and ignorance, impartiality issues which cannot be resolved by any constitutional speech restriction, ${ }^{224}$ and the chilling effect that a speech restriction will have at its margins-the fact that the rule this Comment proposes does not solve all of them does not militate in favor of no restriction at all or a more limited restriction. No rule will solve every problem. Instead, such dilemmas call into question whether existing selection processes are the proper ways to choose judges. Regardless of which selection process is employed, however, preservation of the proper role of the judiciary requires some restrictions on candidates' speech. Without this check, there is nothing but the conscience of the majority to prevent the trampling of minority interests, and history has demonstrated that this often will not be sufficient. ${ }^{225}$ We should recall the

223 MCFADDEN, supra note 2, at 75 .

${ }_{224}$ These include such problems as express or implied mandates based upon an individual's prior opinions or the statements of others. Although the same problems of judicial impartiality are implicated, no rule could adequately prevent these results.

${ }_{925}$ See, e.g., Korematsu v. United States, 323 U.S. 214 (1944) (upholding the constitutionality of the internment of Japanese-Americans during World War II); Plessy v. Ferguson, 163 U.S. 537 (1896) (finding constitutional "separate but equal" treatment of individuals based upon race), overruled by Brown v. Board of Educ., 347 U.S. 483 
words of Charles Evans Hughes: "We are under a Constitution, but the Constitution is what the judges say it is, and the judiciary is the safeguard of our liberty and of our property under the Constitution." ${ }^{226}$ It would be a mistake to allow this safeguard to depend upon the whims and predilections of the majority.

(1954).

${ }^{226}$ Charles E. Hughes, Speech to the Elmira, New York, Chamber of Commerce (May 3, 1907), in 1 MERLOJ. PUSEY, CHARLES EVANS HUGHES 204 (1951). 